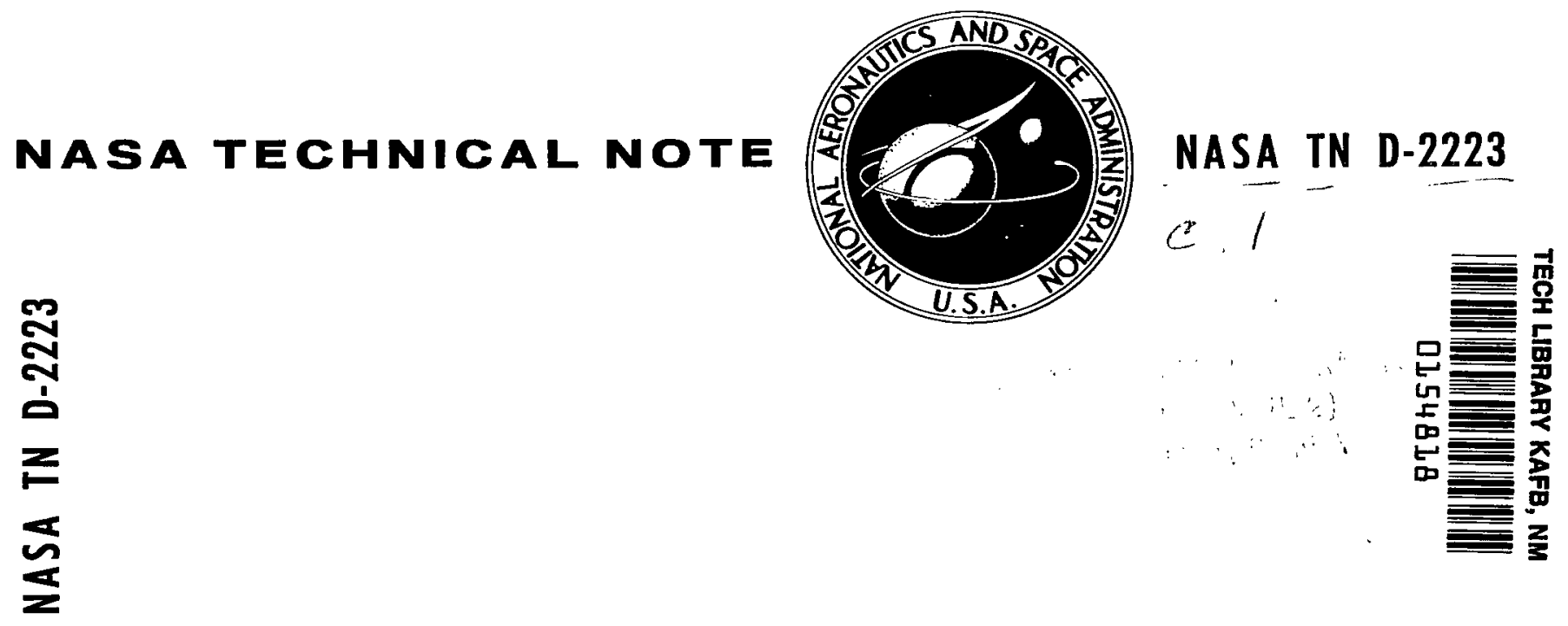

\title{
EVALUATION OF JOURNAL BEARINGS \\ OF VARIOUS MATERIALS IN \\ LOW-VISCOSITY FLUIDS, LIQUID \\ NITROGEN, AND LIQUID OXYGEN
}

by Robert E. Cunningham and William J. Anderson

Lewis Research Center

Cleveland, Obio

NATIONAL AERONAUTICS AND SPACE ADMINISTRATION - WASHINGTON, D. C. - NOVEMBER 1964 
EVALUATION OF JOURNAL BEARINGS OF VARIOUS MATERIALS

IN LOW-VISCOSITY FLUIDS, LIQUID NITROGEN, AND LIQUID OXYGEN

By Robert E. Cunningham and William J. Anderson

Lewis Research Center

Cleveland, Ohio

NATIONAL AERONAUTICS AND SPACE ADMINISTRATION

For sale by the Office of Technical Services, Department of Commerce, Woshington, D.C. 20230 -- Price $\$ 0.75$ 


\section{EVATUATION OF JOURNAL BEARINGS OF VARTOUS MATERTALS}

IN IOW-VISCOSITY FIUIDS, LIQUID NITROGEN,

AND LIQUID OXYGEN

by Robert E. Cunningham and William J. Anderson

Lewis Research Center

\section{SUMMARY}

An experimental investigation was undertaken to determine the feasibility of operating journal bearings in cryogenic liquids at surface speeds comparable to those of current generation oxidant turbopumps. Tests were conducted with 1.0- and 1.5-inch-diameter bearings.

Results from tests in liquid nitrogen and liquid oxygen were generally poor due to the difficulty of maintaining a hydrodynamic film. It is hypothesized that boiling of the cryogenic fluids may have occurred within the bearing clearance area, creating a two-phase-flow condition. A sharp decrease in the effective viscosity and in the bearing load-carrying capacity resulted.

The best performance from tests with journal bearings fully immersed in liquid-oxygen was obtained with (I) fused polytetrafluoroethylene (PTF' coated wrought-nickel-copper alloy sleeves, (2) a 15-percent glass-filled PTPE liner on steel, and (3) PIFT plus lead in sintered bronze. These materials were capable of sustaining moderate loads at surface speeds to 76 feet per second for a short duration. Liquid-oxygen pressure fed to the bearings at approximately 5 pounds per square inch gage above atmospheric pressure (boiling point, $-302^{\circ} \mathrm{F}$ ) did not improve performance over the tests fully immersed at atmospheric pressure.

Results of screening tests conducted in a low-viscosity hydrocarbon with a number of materials showed good agreement with hydrodynamic theory. Hydrodynamic films were maintained over a range of surface speeds to 107 feet per second at unit loads to 200 pounds per square inch.

\section{INTRODUCTION}

Present generation liquid-chemical-propulsion systems utilize high-speed turbopumps to transfer cryogenic liquid propellants from storage tanks to the rocket-engine combustion chamber. It is desirable to operate the shaft bearings immersed in the working fluid. Two decided advantages immediately apparent 
are (1) weight reduction by the elimination of a separate lubrication system and (2) simplification of design by the overall reduction in the number of shaft seals normally required with conventional lubricants. To achieve maximum weight reduction and reduce complexity, it is necessary to use the propellants both to lubricate and to cool the bearings in the fuel and the oxidant systems. This report is concerned with journal bearings that would be suitable for operation in cryogenic oxidants.

The decision to evaluate plain journal bearings rather than rollingcontact bearings was based primarily on the greater number of candidate materials for sliding bearings that are potentially compatible with strong oxidizers. Secondly, lower unit pressures are obtained in sliding bearings as compared with a rolling bearing at the same load.

Basically, an ideal bearing lubricant performs two functions: (1) it prevents intimate contact of journal and bearing surfaces, and (2) it carries away the heat generated in shearing the film. Liquid oxygen, for example, at its boiling point of $-297^{\circ} \mathrm{F}$ affords an excellent heat sink; however, its extremely low viscosity of $0.0274 \times 10^{-6} \mathrm{reyn}$ ( $1 \mathrm{~b}-\mathrm{sec} / \mathrm{sq}$ in.) limits the amount of load pressure that can be supported with a realistic film thickness. Hydrodynamic bearing theory states that load-carrying capacity varies directly with lubricant viscosity and journal speed. Because of the low viscosity of liquid oxygen as compared with conventional lubricants, it is reasonable to assume that bearings will, at times, operate under boundary lubrication conditions. This being the case, material selection under these conditions is of prime importance.

A preliminary two-phase screening program was conducted to evaluate qualitatively a number of promising materials. The object of these screening tests was to determine the speed and load limitations of the candidate materials. In the initial phase, a low-viscosity hydrocarbon (hexane), which has an absolute viscosity of $0.043 \times 10^{-6}$ reyn at $75^{\circ} \mathrm{F}$, was used as a Iubricant. The second phase was conducted in liquid nitrogen (absolute viscosity, 0.023×10-6 reyn at $-320^{\circ} \mathrm{F}$ ) with those materials that had exhibited good performance in the room-temperature hexane tests. In addition to possessing good bearing properties, the materials chosen for testing would have to be resistant to chemical attack by strong oxidizers (such as liquid $\mathrm{O}_{2}$ and liquid $\mathrm{F}_{2}$ ) used as high-energy propellants. Consideration also had to be given to dimensional stability and retention of certain desirable physical properties at low temperatures.

The low-temperature-test results reported herein are for journal bearings operating fully immersed in liquid nitrogen and liquid oxygen at atmospheric pressure. Some tests were also conducted with journal bearings pressure-fed with Iiquid oxygen.

The object of this investigation was to determine the load-carrying capabilities and the speed limitations of various materials that have potential as bearings in cryogenic oxidant pumps. Based on a typical turbopump application, these bearings would have to sustain steady loads of 68 to 151 pounds per square inch (shaft diam., $1.5 \mathrm{in.;}$ bearing length, $1.5 \mathrm{in.}$ ) at a speed of $12,000 \mathrm{rpm}$. 
A qualitative evaluation was made of bearing and journal wear. Bearing friction torque at varying speeds and loads was recorded for the low-viscosityhydrocarbon tests. Various lubricating groove arrangements were tested, and. the diametral clearance was varied in an attempt to establish a load-carrying hydrodynamic film.

Nominal $1 \frac{1}{2}$-inch-bore by $1 \frac{1}{2}$-inch-length bearings were tested in hexane at radial loads to 500 pounds and journal speeds to 17,100 rpm. Nominal l-inchbore by l-inch-length bearings were tested in liquid nitrogen and liquid oxygen at radial loads to 200 pounds per square inch and journal speeds to 25,000 and 17,500 rpm, respectively.

\section{SYMBOLS}

$c_{d}$ diametral bearing clearance, in.

$c_{r} \quad$ radial bearing clearance, in.

d bearing diameter, in.

F frictional force, lb

f coefficient of friction, F/W, dimensionless

$f\left(r / c_{r}\right)$ friction variable, dimensionless

$\imath \quad$ bearing length, in.

$\mathrm{p}^{\prime} \quad$ unit load on projected area, $\mathrm{P} / 2 \mathrm{~d}, \mathrm{lb} / \mathrm{sq}$ in.

r bearing radius, in.

$\mathrm{S}$

Sommerfeld number, $\frac{\mu N^{\prime}}{p^{\prime}}\left(\frac{r}{c_{r}}\right)^{2}$, dimensionless

IN' journal speed, rps

$N_{\text {T }} \quad$ transitional journal speed from laminar to turbulent regime,

$$
\frac{4 I . I v}{\pi d c_{r}} \sqrt{\frac{d}{2 c_{r}}}, \operatorname{rps}
$$

W

applied load, Ib

$\mu$

absolute viscosity, reyns (1b-sec/sq in.)

$v$

kinematic viscosity, centistokes (sq in./sec) 


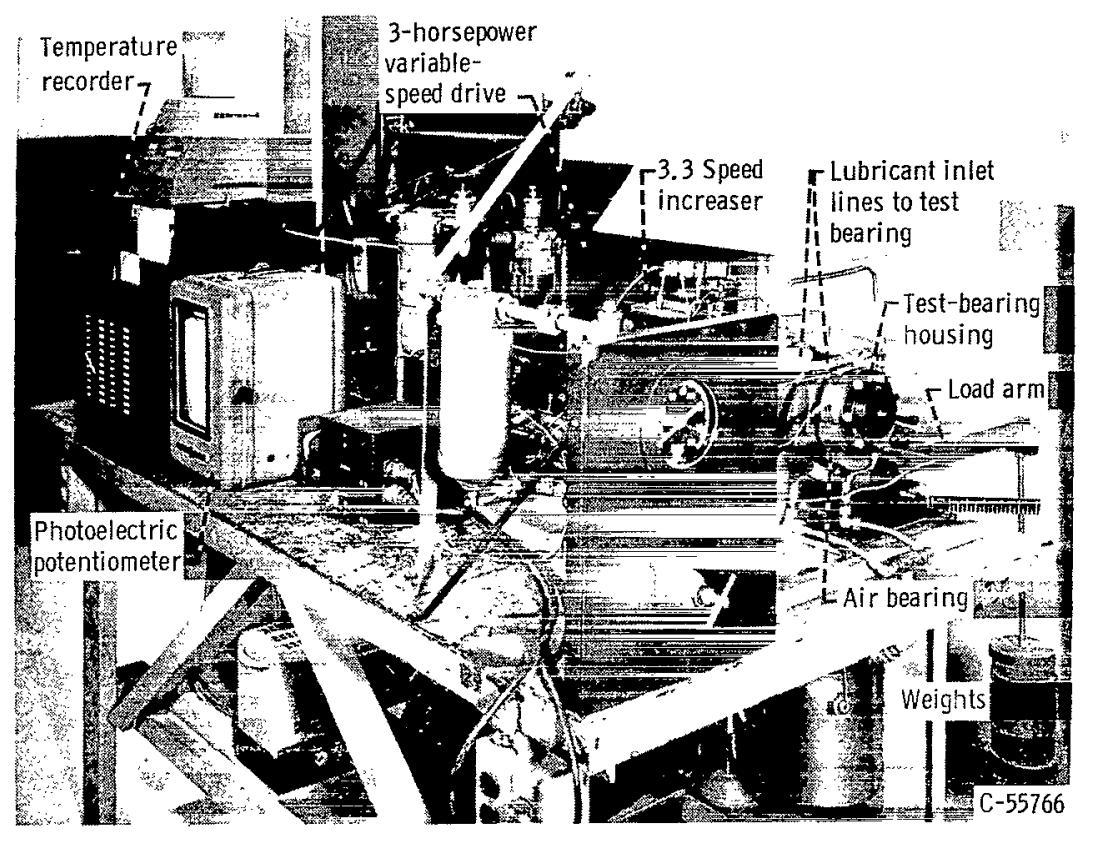

Figure 1. - Bearing screening rig used in tests with hexane.

\section{APPARATUS}

Screening Rig

The apparatus used in conducting the screening tests with hexane is shown in figure 1. A 3.3 speed increaser is coupled to a 3 -horsepower variable-speed drive motor on one end and to the test shaft on the other through a shear pin and flexible coupling. The speed range of the test shaft was from 2000 to $17,100 \mathrm{rpm}$; shaft speed was measured by a chronometric tachometer.

Static weights positioned at one end of a

lever arm with a ratio of 10 were used to apply a radial. load to the test bearing. This load was transmitted to the test-bearing housing through an externally pressurized air bearing so that the housing was free to rotate for measurement of bearing friction torque. The tangential friction force produced in the bearing was sensed by an electrical-resistance strain-gage beam and recorded on a photoeletric potentiometer. To minimize any spurious torques in the system, the test lubricant was introduced to the bearing housing through two pieces of flexible tubing. The tubing was arranged in symmetric coils, one on each side of the housing centerline, to cancel out any reaction couples produced by the lubricant flow. The lubricant flow from the bearing was collected and returned to the sump by means of catch basins. A three-way valve in the return line provided a means for flow measurement. Bearing back and lubricant temperatures were measured by iron-constantan thermocouples.

The bearings were 1.5 inches (nominal) in inside diameter by 1.5 inches (nominal) long. The lubricant was introduced to the bearing through a 0.125inch-diameter hole into an axial spreader groove opposite the applied load as in reference 1. A three-axial-groove configuration was tested to determine the effects, if any, on inhibiting half-frequency whirl (ref. 2). These two bearing-groove designs are shown in figures $2(a)$ and (b). Test journals in most cases were SAE-4340 steel treated to a Rockwell $\mathrm{C}$ hardness of 35 and finished to 5 to 10 microinches rms.

\section{Cryogenic Rig}

Drive and load system. - A 10-horsepower variable-speed direct-current drive motor is coupled to a 14.35 speed increaser through a flexible coupling. The vertical test shaft is supported by a ball and roller bearing and is 


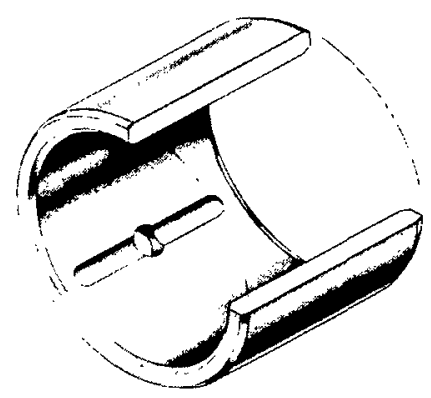

(a)

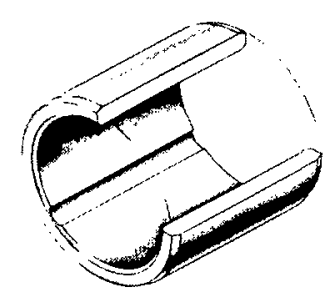

(c)

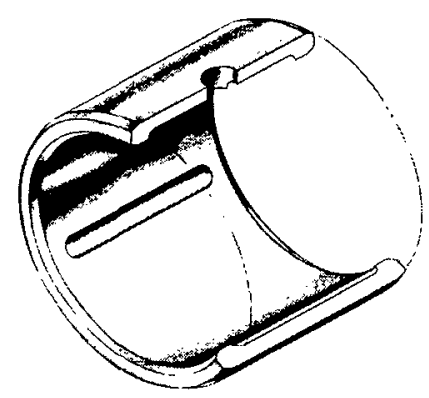

(b)

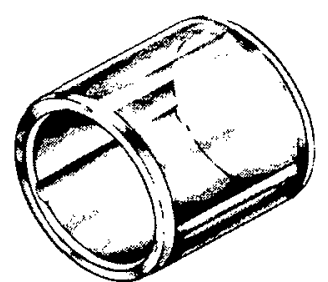

(d)

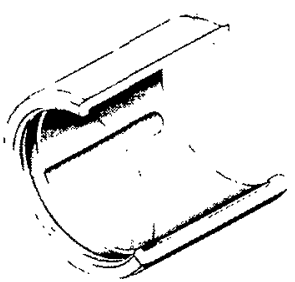

(e)

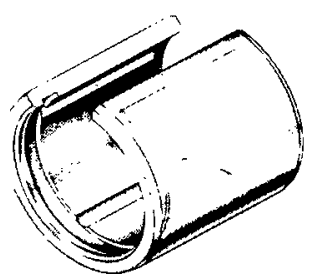

(f)

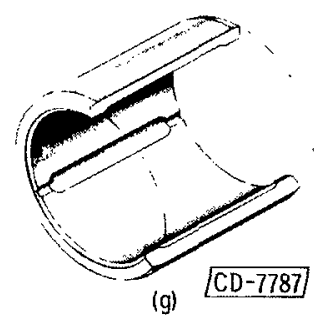

(g)

Figure 2. - Types of lubricant supply grooves investigated in hexane, liquid nitrogen, and liquid oxygen.

\begin{abstract}
tains the oxidant that
\end{abstract}
is introduced through a heat-exchanger coil immersed in liquid nitrogen in the center chamber. The outermost chamber is a vacuum jacket to minimize boilofi of the cryogenic liquid. The cryogenic liquid (nitrogen or oxygen) was transferred from a 100-litex Dewar to the test chamber by gas pressurization. The liquid level in the test chamber was sensed by a specially designed capacitance probe and was read on a milliammeter. In the tests where the liquid oxygen was supplied to the bearing at approximately 5 pounds per square inch gage, the heat exchanger and the nitrogen jacket were removed and a transfer line was added that introduced the test fluid directly to the bearing as shown in figure $3(b)$.

Test bearings. - The bearings tested in liquid nitrogen and liquid oxygen were 1.0 inch (nominal) in inside diameter by 1.0 inch (nominal) Iong. These bearings were tested fully immersed in liquid nitrogen and both fully immersed and pressure-fed in liquid oxygen. Various lubricant-groove configurations, both circumferential and axial, were tested and are shown in figures $2(c)$ to $(\mathrm{g})$. The test journals in most cases were made of hardenable stainless steel; however, a wrought nickel-copper alloy and a hardenable alloy steel were also tested. 


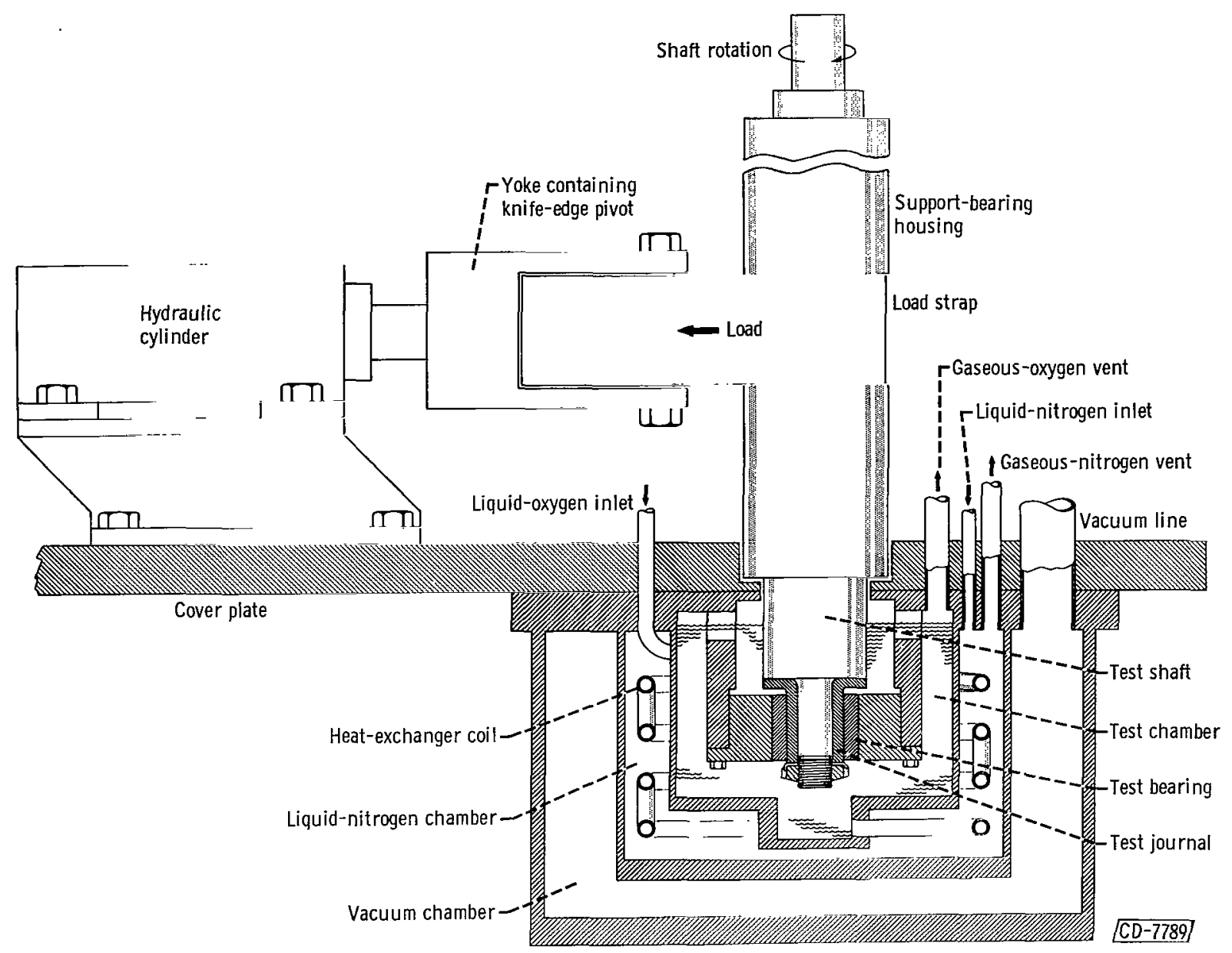

(a) Bearing fully immersed at atmospheric pressure.

Figure 3. - Schematic drawing of cryogenic bearing-test rig.

\section{PROCEDURE}

\section{Screening Tests}

Prior to each test series a bearing was assembled in a housing with a radial interference fit. An average of nine measurements with a dial bore gage determined the bearing inside diameter to within 0.0001 inch. From this measurement a journal diameter was specified to give a predetermined running clearance for any given test.

The test-lubricant pump was started and the inlet pressure to the bearing adjusted to 10 pounds per square inch gage. To prevent galling or scoring of the bearing and journal surfaces, the drive motor was started prior to the application of any radial load. With the test shaft running at its minimum speed of $2000 \mathrm{rpm}$, weights were added to the load arm and the torque readings checked to see whether or not the bearing was running with a hydrodynamic film. For a given radial load, the speed was increased in nominal 2500-rpm increments up to a maximum nominal speed of $15,000 \mathrm{rpm}$. The load was then increased by 


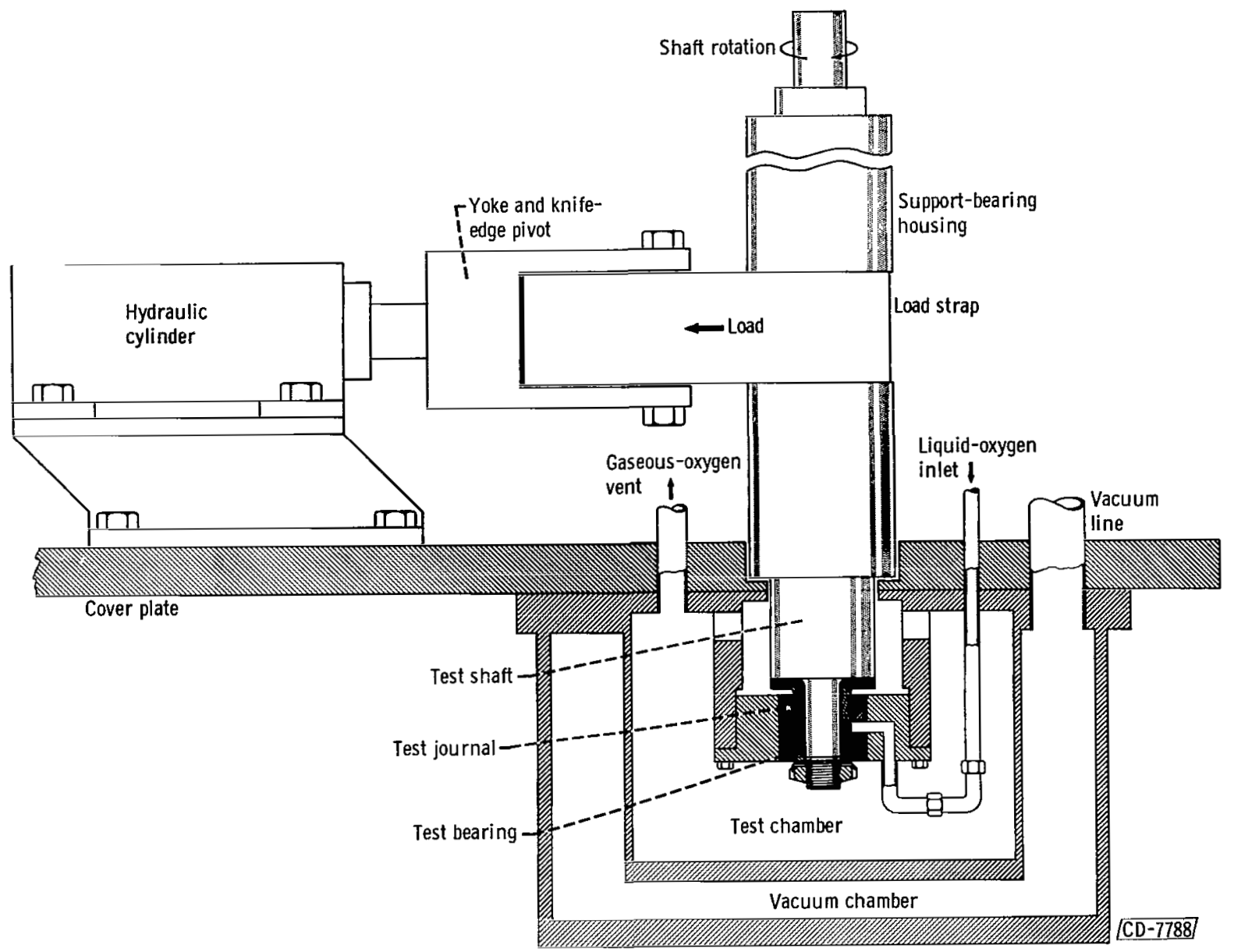

(b) Pressure-fed system.

Figure 3. - Concluded. Schematic drawing of cryogenic bearing-test rig.

100 pounds on a succeeding run and the speed varied as before. This procedure was repeated until a maximum load of 500 pounds was reached or until a failure terminated the test. A run was considered successful if the maximum speed was attained under a given radial load for 30 minutes.

\section{Cryogenic Bearing Tests}

The test bearing inside diameter was measured and a journal size was specified to provide a predetermined running clearance at liquid-bath temperature. To ensure the removal of any organic contaminants, each component of the test bearing was thoroughly cleaned in 1, 1, 1,-trichloroethane and then rinsed in acetone. Journals were scrubbed with levigated alumina until tap water would completely wet the surface indicating the absence of any organic films.

Iiquid nitrogen was introduced into the chamber surrounding the oxidant or test chamber. Sufficient time was allowed for chamber walls to reach tem- 
perature equilibrium before the low-temperature test fluid was introduced into the test chamber. Once a stable liquid level of approximately 2 inches above the test bearing could be maintained at a Dewar gas pressure of 3 pounds per square inch gage, the drive motor was started. At startup, the test shaft would accelerate to a minimum value of $400 \mathrm{rpm}$. The speed was slowly increased to at least $1000 \mathrm{rpm}$ before any load was applied. With a given load applied the speed was increased in nominal 2500-rpm increments to a maximum of 25,000 rpm. The load was varied in 25-pound increments whenever possible. Motor input volts and amperes were recorded at each speed and load change. A test was terminated if (1) the armature current exceeded 125 percent of the rated amperes for more than 5 minutes, (2) the ammeter surged, (3) severe noise and/or vibrations occurred, or. (4) seizure of the test bearing occurred.

\section{RESULTS AIVD DISCUSSION}

\section{Screening Tests in Hexane}

The results of preliminary tests with hexane as a lubricant are listed in table I. The metal combination exhibiting the best performance under hydrodynamic and boundary lubricating conditions was a high-lead-bearing bronze

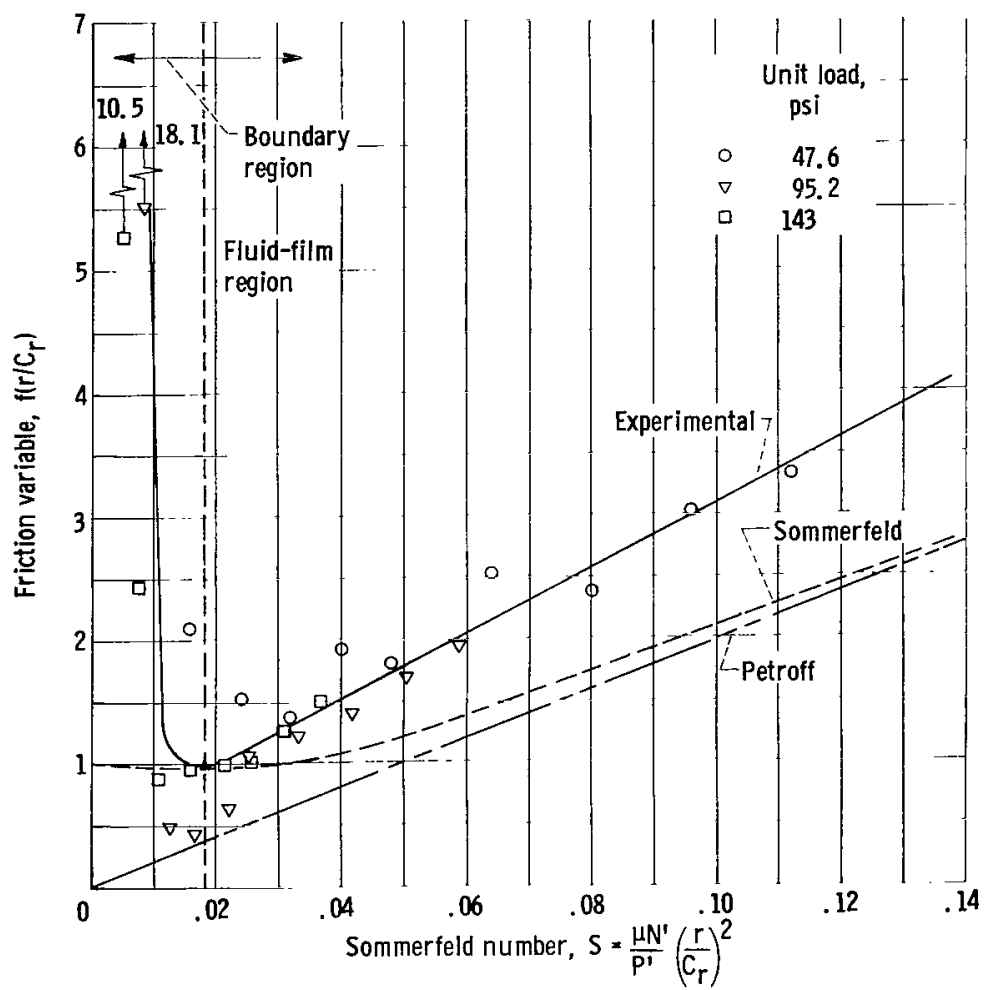

Figure 4. - Comparison of experimental data with theoretical data for loads of 100,200 , and 300 pounds. Bearing, high-lead-bearing bronze; bearing diameter, $1 \frac{1}{2}$ inches; journal, steel; diametral clearance, 0.0021 inch; hexane inlet pressure (fed through $1 / 2$-in.-diam, hole), 10 pounds per square inch gage; absolute viscosity, $0.043 \times 10^{-6}$ reyns at $75^{\circ} \mathrm{F}$; speed, 2000 to $14,000 \mathrm{rpm}$. running against an SAE-4340 journal. Satisfactory performance was also obtained with an SAE-64-bearing bronze against an SAE-4340 journal.

\section{Metallic materials. -}

The high-lead-bearing bronze material, because of its reliable performance, was used in several investigations to obtain friction-torque data for comparison with hydrodynamic theory. Experimental values of friction variable are plotted against Sommerfeld number in figure 4. Also plotted in figure 4 are friction variables against Sommerfeld number by using the Petroff, Ocvirk (ref. 3), and Sormerfeld theories (ref. 4). The high experimental values of friction variable show that a rupture of the hydrodynamic film occurred at values of the Sommerfeld number less than 0.02 . For values less than 0.02 , boundary lubrication conditions existed; for 


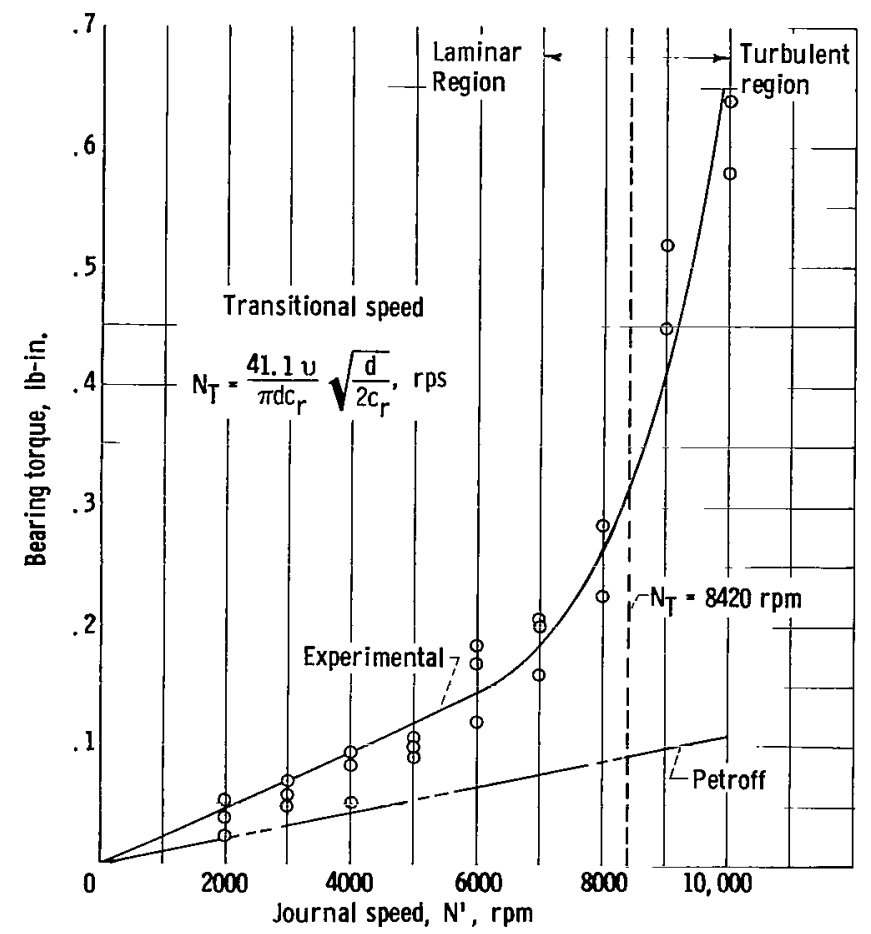

Figure 5. - Zero-load friction torque plotted against journal speed in hexane for comparison of experimental data with theoretical data. Bearing, high-lead-bearing bronze, bearing diameter, $1 \frac{1}{2}$ inches; bearing length, $1 \frac{1}{2}$ inches; journal, steel; diametral 2 clearance, 0.0021 inch; hexane inlet pressure (fed through 1/8-in.-diam. hole), 10 pounds per square inch gage; absolute viscosity, $0.043 \times 10^{-6}$ reyns at $75^{\circ} \mathrm{F}$; journal speed, 2000 to $10,000 \mathrm{rpm}$. values above 0.02 , this bearing operated with a full fluid film. The knee of this curve is dependent upon the frictional characteristics of the bearing material (ref. 5).

Bearing friction torque was obtained over a range of speeds to determine the onset of turbulence. These data are plotted in figure 5. The general shape of the curve is in good agreement with data obtained in references 6 and 7 for turbulent flow investigations. A critical or transitional shaft speed was calculated for this bearing by using Taylor's criterion (ref. 8) as modified by Wilcock. The calculated value is shown in figure 5 as a dotted line and falls close to the actual shaft speed where friction torque no longer increases linearly with an increase in speed.

Plastic materials. - of the various plastic materials tested in hexane (table $I(b)$ ), the fused polytetrafluoroethylene (PTFE) on wrought nickel-copper alloy per-

formed the best. The test conducted at a maximum journal speed of 107 feet per second and a maximum unit pressure of 204 pounds per square inch was completed without any indication of bearing distress. The only visual evidence of the material having been tested was a slight glazed appearance of the surface in the load-carrying area (fig. 6(a)). Satisfactory performance was also obtained with a commercially available material (PTFE plus $\mathrm{Pb}$ in sintered bronze). This bearing was in excellent condition at the conclusion of the test series, and only a light polishing of the surface was evident as a result of contact with the journal on starting and stopping (fig. 6(b)).

Ceramic and cermet materials. - The results of screening tests with two ceramic materials and one cermet material are shown in table $I(c)$. The performance of these materials was poor. Failure in all cases was due to seizure, indicating that these materials, when used in plain journal bearings, will not perform satisfactorily in the boundary lubrication regime.

Screening Tests in Liquid Nitrogen

The results of these tests are presented in table II. The bearing of 

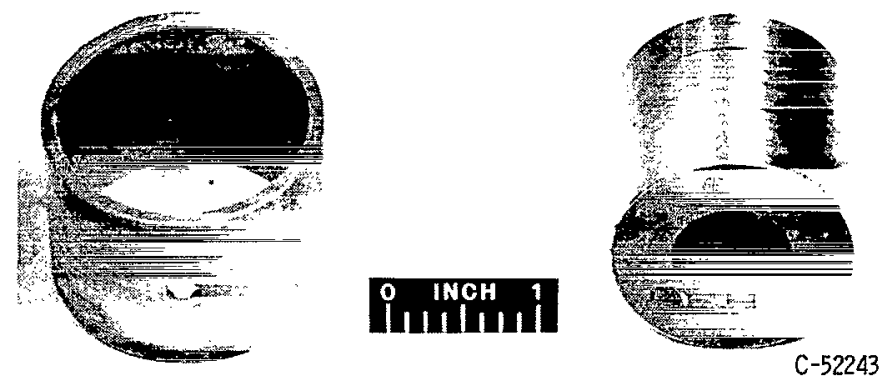

(a) Fused polytetrafluoroethylene on wrought nickel-copper alloy.
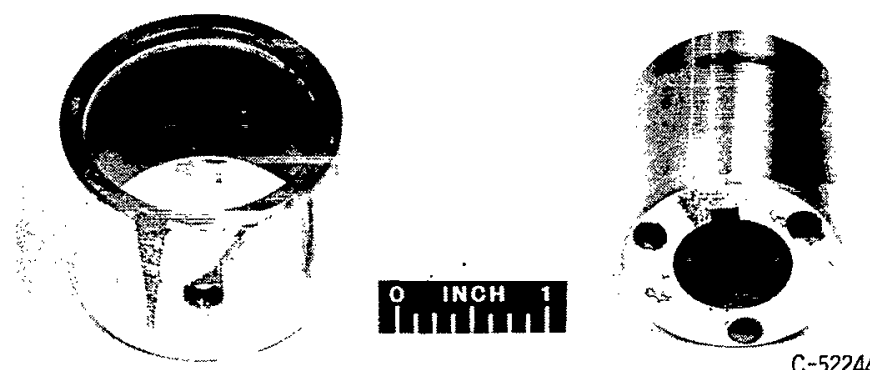

(b) Polytetrafluoroethylene plus lead in sintered bronze.

Figure 6. - Results of screening tests in hexane. fused PIH'E on wrought nickelcopper alloy, as in the hexane tests, again demonstrated performance superior to that of either the SAE-64 and the leadbearing bronzes or the bearing of PTH'E plus lead in sintered bronze. A maximum unit load of 215 pounds per square inch was sustained by the fused-PIF' on wrought nickel-copper alloy bearing for 5 minutes at 15,000 rpm. The motor armature current during this run fluctuated excessively, indicating operation in the boundary Iubrication regime. Examination of the bearing at the completion of the test showed the PTH'E Iiner to be completely worm away and the wrought nickelcopper alloy sleeve to be deeply scored in the load zone (fig. 7(a)). PTH'E and metal debris were present in the test chamber.

The overall performance of the bearing of PTFE plus lead in sintered bronze was superior to that of

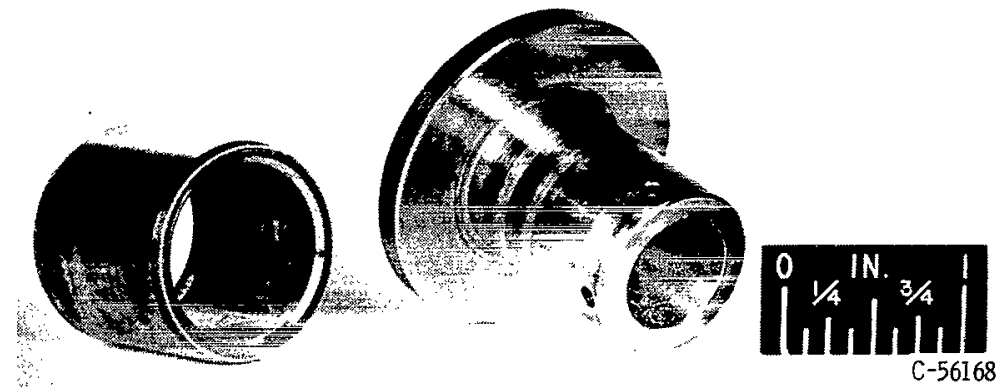

(a) Fused polytetrafluoroethylene on wrought nickel-copper alloy.
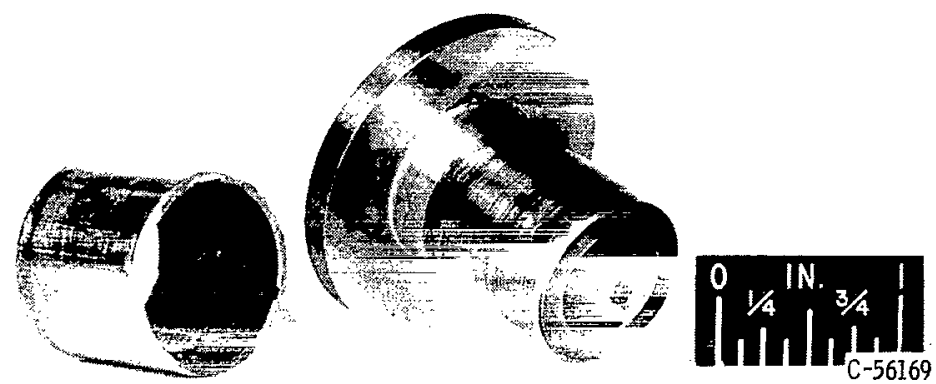

(b) Polytetrafluoroethylene plus lead in sintered bronze.

Figure 7. - Results of screening tests in liquid-nitrogen. either the SAE-64- or the lead-bearing bronzes. In one test a load of 45 pounds per square inch was carried at a surface speed of 87.5 feet per second with the bearing fully immersed in liquid nitrogen. Diametral clearances were increased, and three equally spaced. axial spreader grooves (fig. 2) were added to increase the supply of Iubricant to the bearing clearance area. These changes resulted in some improvement as shown in table II. The bearing was able to support a load of 45 pounds per square inch at a surface speed of 87.5 feet per second. The extent of bearing wear and journal scoring are shown in figure $7(b)$. Test results for 
the SAE-64- and the lead-bearing bronzes show that the SAE-64 phosphor bronze was superior to the high-lead-bearing bronze that was unable to carry any load at a.I.

\section{Tests in Liquid Oxygen}

Fully immersed at atmospheric pressure. - Results of these tests are presented in table III(a). The fused-PIFE coating on wrought nickel-copper alloy and the glass-filled-PIFE on steel bearings, as in the hexane and liquidnitrogen tests, performed better than the other materials tested; however, there were no tests that reached both objectives of a surface speed of 78.5 feet per second and a load of 100 pounds per square inch. One exception was a PITH'E Iiner (15-percent glass-filled) on perforated steel that carried a load of 160 pounds per square inch at 65.5 feet per second for approximately 7 minutes, at which time impending seizure dictated a reduction in the load and speed. Performance on a second test of this material was not nearly as good. This test was run on a split bushing that is shown with the journal in figure 8(a). A white powdery wear debris was evident in the test chamber and on the adapter parts. The journal was darkened indicating that high temperatures were generated at the joumal and bearing interface at the high mbbing speeds.

The bearings of fused PTHE on wrought nickel-copper alloy and PTFE plus lead in sintered bronze were capable of sustaining only moderately light loads at surface speeds considerably less than the original test objectives. The latter material showed only light wear in the load zone, whereas the fusedPIFE coating in one test at the maximum surface speed of 76.5 feet per second and load of 36 pounds per square inch was completely worn through to the

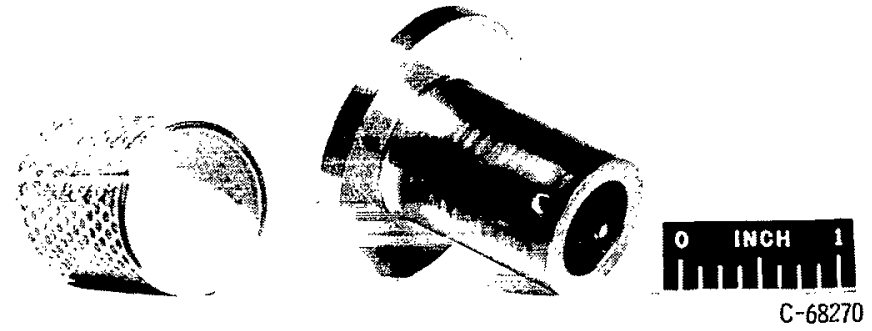

(a) Polytetrafluoroethylene liner (15-percent-glass-filled) on perforated steel.
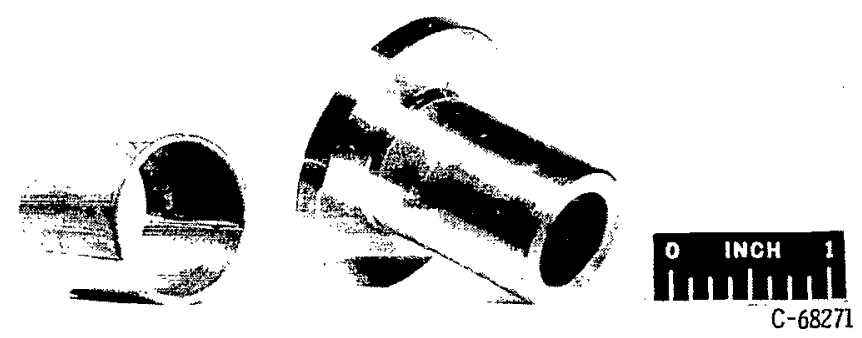

(b) Polytetrafluoroethylene plus lead in sintered bronze.

Figure 8. - Results of tests in liquid oxygen (fully immersed at $14.7 \mathrm{lb} / \mathrm{sq}$ in.). wrought nickel-copper alloy backing sleeve. The bearing and journal of PTH' plus lead in sintered bronze are shown in figure $8(b)$. The single axial groove in the bearing can be seen. The I/8-inch-diameter hole located in the journal midway between the ends was drilled coincident with radial passageways in the shaft that led to a central shaft recess. This was done in an effort to improve the flow of Iiquid oxygen to the bearing by exploiting the centrifugal pressure head developed in the entrapped fluid in this recess.

Two phenolic-impregnated mechanical-carbon bearings were tested. One test was terminated after a short time due to excessive drive torque even at very nominal loads. The second test on 
a bearing with a significantly larger clearance seized at 2500 rpm without any load being applied.

Pressure-fed tests. - The results of these tests are presented in table III $(b)$. Several mechanical-grade carbon materials with phenolic-resin, halidesalt, and PTFE impregnants were tested and compared with fused PTFF on wrought nickel-copper alloy. ' The latter material performed slightly better than the carbon materials. In two of the pressure-fed tests, the general performance was poorer than in the fully immersed tests. The maximum speed attainable was 44 feet per second at a load of 41 pounds per square inch compared with 76.5 feet per second at 36 pounds per square inch in the fully immersed tests. All bearings of carbon compositions experienced seizure at moderate speeds and loads, or tests were terminated because of high motor armature current. The fused-PIFE liners in both cases were worn away and the journal was badly scored (fig. 9(a)). The bearing of halide-salt-impregnated carbon is shown in figure $9(\mathrm{~b})$. The bearing of PTH'E-impregnated carbon that showed Iight scoring and polishing is shown in figure $9(\mathrm{c})$.

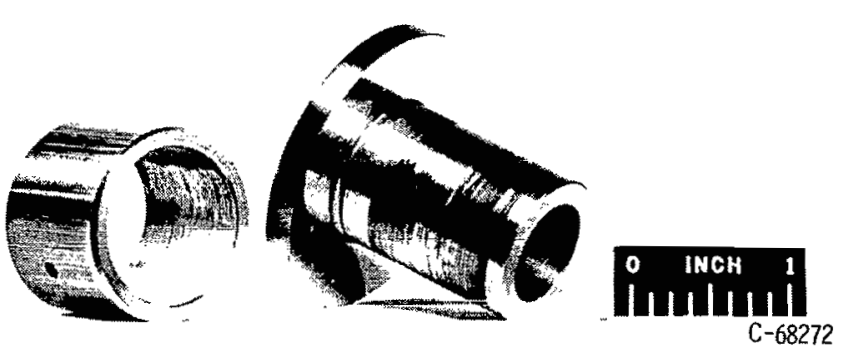

(a) Fused polytetrafluoroethylene on wrought nickel-copper alloy.
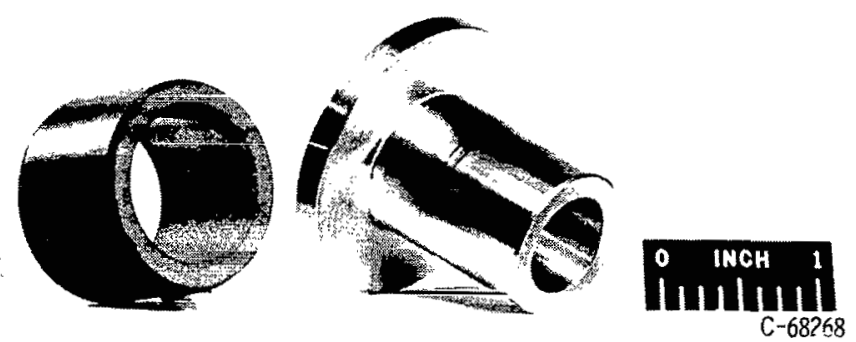

(b) Halide-salt-impregnated mechanical-grade carbon.

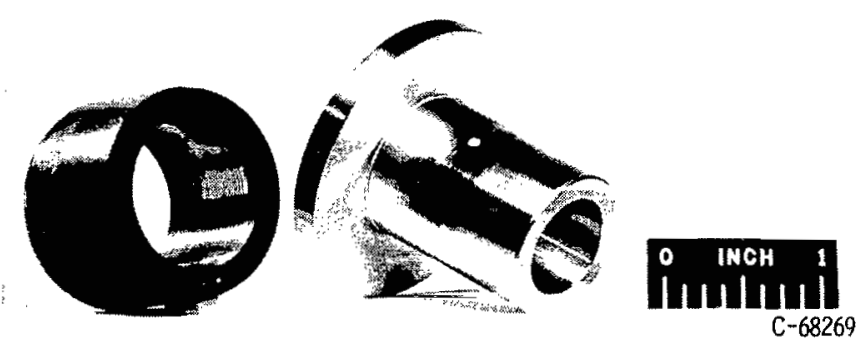

(c) Polytetrafluoroethylene-impregnated mechanical-grade carbon.

Figure 9. - Results of tests in liquid oxygen (externally pressurized at $5 \mathrm{lb} / \mathrm{sq}$ in. gage).
It is hypothesized that the generally poor performance of these materials in the cryogenic fluids is due primarily to the fact that these fluids are at or near their boiling points. Any energy input into the fluid, for instance, through surface contact at startup or from viscous shear, causes it to flash into a vapor, resulting in two-phase flow within the bearing. The presence of a two-phase flow would sharply decrease the load-carrying capacity by a further reduction in the viscosity.

In order to ensure a full fluid film in the bearing, liquid oxygen was supplied directly to the clearance area $180^{\circ}$ opposite the applied radial load at a pressure of 5 pounds per square inch gage above atmospheric. The boiling point of liquid oxygen at this pressure was $-302^{\circ} \mathrm{F}$. The test results did not indicate any improvement, and, in some cases, performance was not as good. Results of tests when liquid oxygen was subcooled to approximately $-304^{\circ} \mathrm{F}$ by means of the liquidnitrogen jacket were also negative. 
For any given bearing geometry the load-carrying capacity is a direct function of lubricant viscosity and shaft speed in the hydrodynamic regime. In boundary lubrication as applied to journal bearings, however, the load capacity varies inversely as the speed and is dependent on certain physical characteristics of the material as well as bearing geometry, surface finishes, and the amount of wear that can be tolerated in the bearing (refs. 5 and 9).

\section{SUMMARY OF RESULTS}

A number of tests were conducted with 1.0- to 1.5-inch-diameter journal bearings of various materials with a low-viscosity hydrocarbon, liquid nitrogen, and liquid oxygen as lubricants. The three fluids had comparable viscosities at test conditions. These tests, which were run over a range of journal surface speeds to 109 feet per second (25,000 rpm) and loads to 220 pounds per square inch, revealed the following results:

1. The generally poor bearing performance experienced in liquid oxygen was in direct contrast to the relatively good results obtained with several material combinations in the hydrocarbon screening tests. This poor performance is attributed to the operation of the bearings in the cryogenic fluids while at or near their boiling points, where only a slight energy input causes the fluid to flash into a vapor, resulting in two-phase flow.

2. Fully immersed tests in liquid oxygen for six different materials showed that only three were capable of sustaining even nominal loads (36 psi) at shaft speeds of $10,000 \mathrm{rpm}$ ( $14 \mathrm{ft} / \mathrm{sec}$ ) and above for short durations. These materials were (1) fused PTH' on wrought nickel-copper alloy, (2) 15-percentglass-filled PTHE on perforated steel, and (3) PTFE plus lead in sintered. bronze. Thermal degradation of the liners through frictional heating at high rubbing speeds caused excessive wear and ultimate failure of the bearing.

3. Two pressure-fed tests in liquid oxygen of a bearing of fused-PTH E coating on wrought nickel-copper alloy showed load-carrying capabilities of 36 and 41 pounds per square inch at a maximum speed of $10,000 \mathrm{rpm}$ ( $44 \mathrm{ft} / \mathrm{sec}$ ). Impregnated carbon bearings generally did not perform as well under these conditions as did the fused-PTHE-coated wrought nickel-copper alloy bearings.

4. Experimental values of friction variable at varying Sommerfeld numbers obtained in screening tests conducted in a low-viscosity $(0.043 \times 10-6$ reyn at $75^{\circ} \mathrm{F}$ ) hydrocarbon (hexane) correlated well with the theory. The bearing material used in these tests was a high-lead-bearing bronze operating against an SAE-4340 steel journal. A definite rupture of the lubricating film occurred in some tests at a Sommerfeld number of less than 0.02. The experimental curve of friction variable as a function of Sommerfeld number is of the same general shape as that obtained by many other investigators.

5. Experimental values of bearing friction torque at zero load established a shaft speed for a given bearing geometry where transition from Iaminar to turbulent flow occurs. The plotted curve is in good agreement with results published by other investigators. 
6. A number of tests were conducted in liquid nitrogen on those materials that performed satisfactorily in hexane. The bearings of fused-PTF E coating on wrought nickel-copper alloy and PDFE plus lead in sintered bronze were able to sustain higher loads at higher surface speeds and for longer periods of time than the SAE-64- and the high-lead bearing bronzes.

Lewis Research Center

National Aeronautics and Space Administration

Cleveland, Ohio, August 26, 1964

RE'HEREIVCES

1. McKee, S. A.: Oil Flow in Plain Journal Bearings. Trans. ASME, vol. 74, no. 5, July 1952, pp. 841-848.

2. Pinkus, 0.: Solution of Reynolds' Equation for Finite Joumal Bearings. Trans. ASME, vol. 80, no. 4, May 1958, pp. 858-864.

3. DuBois, George B., and Ocvirk, Fred W.: Analytical Derivation and Experimental Evaluation of Short-Bearing Approximation for Full Jourmal Bearings. NACA Rep. 1157, 1953.

4. Sommerfeld, A. : The Hydrodynamic Theory of Lubrication Friction. Zs. Math. und Physik, vol. 50, nos. 1-2, 1904, pp. 97-155.

5. McKee, S. A., White, H. S., Bell, A. D., and Swindells, J. F.: Performance Characteristics of Journal Bearings with Forced-Feed Iubrication. NASA WR W-54, 1945. (Supersedes NASA ARR 4HI5.)

6. Smith, Melvin I. : Investigation of Certain Aspects of Journal Bearing Performance Under Non-Laminar Flow Conditions. Ph. D. Thesis, Columbia Univ., 1955.

7. Wilcock, D. F.: Turbulence in High-Speed Journal Bearings. Trans. ASME, vol. 72 , no. 6, Aug. 1950, pp. 825-834.

8. Taylor, G. I.: Stability of a Viscous Iiquid Contained Between Two Rotating Cylinders. Phil. Trans. Roy. Soc. (Iondon), ser. A, vol. 223, 1923, pp. 289-343.

9. Shaw, M. C., and Macks, F.: Analysis and Lubrication of Bearings. McGrawHill Book Co., Inc., 1949. 


\section{$\mid$}


TABLE I. - RESULTS OF SCREENING TESTS IN LOW-VISCOSITY FYDROCARBON.

[Bearing I.D., I $\frac{1}{2}$ in. (nominal); bearing length, $1 \frac{1}{2}$ In. (nominal); journal materials, SAE 4340 and chromium plating on SAE 4340 ; surface finish, 5 to $10 \mu \mathrm{in}$. (rms); groove type, see fig. 2(a).]

(a) Metals

\begin{tabular}{|c|c|c|c|c|c|c|c|c|}
\hline \multirow[t]{2}{*}{ Bearing material } & \multirow{2}{*}{$\begin{array}{c}\text { Room- } \\
\text { temperature } \\
\text { diametral } \\
\text { clearance, } \\
\text { in. }\end{array}$} & \multicolumn{2}{|c|}{$\begin{array}{c}\text { Maximum fournal } \\
\text { speed }\end{array}$} & \multirow{2}{*}{$\begin{array}{l}\text { Maximum unit- } \\
\text { bearing load, } \\
\text { psi. }\end{array}$} & \multirow{2}{*}{$\begin{array}{l}\text { Time at maximum } \\
\text { speed and load, } \\
\text { min }\end{array}$} & \multirow{2}{*}{$\begin{array}{l}\text { Total } \\
\text { test } \\
\text { time, } \\
\text { min }\end{array}$} & \multirow[t]{2}{*}{$\begin{array}{l}\text { Reason for } \\
\text { stopping test }\end{array}$} & \multirow{2}{*}{$\begin{array}{c}\text { Bearing surface } \\
\text { condition } \\
\end{array}$} \\
\hline & & $\mathrm{rpm}$ & $\mathrm{ft} / \mathrm{sec}$ & & & & & \\
\hline \multirow{5}{*}{$\begin{array}{l}\text { SAE-64-bearjing } \\
\text { bronze } \\
(80 \% \text { Cu+10\% } \mathrm{Pb} \\
+10 \% \mathrm{Sn})\end{array}$} & \multirow[t]{3}{*}{0.0024} & 15,000 & 107 & 81 & 30 & 225 & $\begin{array}{l}\text { Test objective } \\
\text { attained }\end{array}$ & Did not examine \\
\hline & & 15,000 & 107 & 122 & 30 & 105 & $\begin{array}{c}\text { Test objective } \\
\text { attained }\end{array}$ & Did not examine \\
\hline & & 5,000 & 35 & 122 & 30 & 50 & $\begin{array}{l}\text { Bearing seized when } \\
\text { increasing speed to } \\
7500 \mathrm{rpm}\end{array}$ & $\begin{array}{c}\text { Bearing and fournal scored } \\
\text { and galled }\end{array}$ \\
\hline & \multirow[t]{2}{*}{0.0019} & 15,000 & 107 & 40 & 30 & 120 & $\begin{array}{l}\text { Test objective } \\
\text { attained }\end{array}$ & $\begin{array}{l}\text { Bearing and journal lightly } \\
\text { scored }\end{array}$ \\
\hline & & 12,300 & 87 & 81 & $\cdots$ & 90 & High torque & $\begin{array}{l}\text { Bearing scored; surface } \\
\text { polished in load zone }\end{array}$ \\
\hline \multirow{5}{*}{$\begin{array}{l}\text { High-lead-bearing } \\
\text { bronze } \\
(70 \% \mathrm{Cu}+26 \% \mathrm{~Pb} \\
+4 \% \mathrm{Sn})\end{array}$} & \multirow[t]{5}{*}{0.0015} & \multirow[t]{5}{*}{15,000} & \multirow[t]{5}{*}{107} & 43 & 30 & 90 & $\begin{array}{l}\text { Test objective } \\
\text { attained }\end{array}$ & Did not examine \\
\hline & & & & 88 & 30 & 90 & $\begin{array}{c}\text { Test objective } \\
\text { attained }\end{array}$ & Did not examine \\
\hline & & & & 132 & 30 & 90 & $\begin{array}{l}\text { Teat objective } \\
\text { attained }\end{array}$ & Did not examine \\
\hline & & & & 176 & 30 & 90 & $\begin{array}{c}\text { Test objective } \\
\text { attalned }\end{array}$ & Did not examine \\
\hline & & & & 220 & 30 & 90 & $\begin{array}{l}\text { Test objective } \\
\text { attained }\end{array}$ & $\begin{array}{l}\text { Bearlng surface excellent, } \\
\text { light polishing in load zone }\end{array}$ \\
\hline
\end{tabular}




\begin{tabular}{|c|c|c|c|c|c|c|c|c|}
\hline \multirow{3}{*}{$\begin{array}{c}\text { Silver plating on } \\
\text { wrought nickel- } \\
\text { copper alloy } \\
\text { (67\% } \mathrm{N1}+30 \% \mathrm{Cu} \\
+1.4 \% \mathrm{Fe}+1 \% \mathrm{Mn} \\
+0.05 \% \mathrm{Si}+0.15 \% \mathrm{C} \\
+0.035 \% \mathrm{~S})\end{array}$} & \multirow[t]{3}{*}{0.0016} & 15,000 & 107 & 17 & 30 & 150 & $\begin{array}{l}\text { Test objective } \\
\text { attained }\end{array}$ & Did not examine \\
\hline & & 15,000 & 107 & 40 & 30 & 90 & $\begin{array}{l}\text { Test objective } \\
\text { attained }\end{array}$ & Did not examine \\
\hline & & 14,000 & 100 & 81 & --- & 60 & $\begin{array}{l}\text { Bearing seized when } \\
\text { increasing speed to } \\
\text { 15,000 rpm }\end{array}$ & $\begin{array}{c}\text { Silver wiped and scored in } \\
\text { localized areas, approximately } \\
\frac{1}{38} \mathrm{in} \text {. from each end }\end{array}$ \\
\hline \multirow{2}{*}{$\begin{array}{l}\text { Cold-pressed and } \\
\text { sintered iron alloy } \\
(70 \% \mathrm{Fe}+15 \% \text { Mo } \\
+15 \% \mathrm{Co})\end{array}$} & \multirow[t]{2}{*}{0.0014} & 5,000 & 35 & 17 & --- & 2 & $\begin{array}{l}\text { Bearing seized at } \\
\text { this speed and load }\end{array}$ & Deep score in bearing surface \\
\hline & & 5,000 & 35 & 44 & 30 & 30 & $\begin{array}{l}\text { Seized after ap- } \\
\text { proximately I min } \\
\text { at } 8000 \mathrm{rpm}\end{array}$ & Bearing surface badly galled \\
\hline $\begin{array}{l}\text { Beryllium copper } \\
\text { (wrought) } \\
(2 \% \mathrm{Be}+98 \% \mathrm{Cu})\end{array}$ & 0.0018 & 10,000 & 66 & 44 & 30 & 30 & $\begin{array}{l}\text { Bearing seized at } \\
\text { this speed and load }\end{array}$ & $\begin{array}{l}\text { Distress in localized areas at } \\
\text { bearing extremities; journal } \\
\text { evidenced material pickup }\end{array}$ \\
\hline \multirow{3}{*}{$\begin{array}{r}\text { Aluminum bearing } \\
\text { alloy } \\
(6.5 \% \mathrm{Sn}+1 \% \mathrm{Cu} \\
+1 \% \mathrm{Ni}, \mathrm{bal} . \mathrm{AI})\end{array}$} & \multirow[t]{3}{*}{0.0020} & 14,000 & 93 & 44 & 15 & 105 & $\begin{array}{l}\text { High torque and } \\
\text { rough operation } \\
\text { generally }\end{array}$ & $\begin{array}{c}\text { Bearing lightly scored near } \\
\text { ends }\end{array}$ \\
\hline & & 15,000 & 106 & 88 & 5 & 60 & $\begin{array}{l}\text { High torque and } \\
\text { rough operation } \\
\text { generally }\end{array}$ & Additional scoring \\
\hline & & 4,000 & 26 & 132 & 10 & 10 & Seized & $\begin{array}{l}\text { Bearing galled; heavy scoring } \\
\text { In load zone }\end{array}$ \\
\hline \multirow{2}{*}{$\begin{array}{l}\text { Rhodium plating on } \\
\text { wrought nickel- } \\
\text { copper alloy } \\
\text { (ASTM Bl64) }\end{array}$} & \multirow[t]{2}{*}{0.0018} & 15,000 & 99 & 44 & 2 & 120 & $\begin{array}{l}\text { High torque and } \\
\text { rough operation }\end{array}$ & Light scoring \\
\hline & & 15,000 & 99 & $\overrightarrow{44}$ & 15 & 90 & $\begin{array}{l}\text { Seized when at- } \\
\text { tempting Increase } \\
\text { in load at } 2000 \mathrm{rpm}\end{array}$ & $\begin{array}{l}\text { Galled areas at ends of } \\
\text { bearlng }\end{array}$ \\
\hline \multirow{2}{*}{$\begin{array}{l}\text { Gold plating } \\
\text { on wrought nickel- } \\
\text { copper alloy } \\
\text { (ASTM BI64) }\end{array}$} & \multirow[t]{2}{*}{0.0021} & 14,000 & 92 & 44 & 10 & 80 & $\begin{array}{l}\text { Rig noisy; high } \\
\text { torque }\end{array}$ & Did not examine \\
\hline & & 4,000 & 36 & 88 & -- & $-\infty$ & Selzed & $\begin{array}{l}\text { Narrow band of galled surface } \\
\text { In center extending } 3600 \text { in } \\
\text { circumference }\end{array}$ \\
\hline
\end{tabular}


TABLE I. - Contimued, RESULTS OF SCRFENING TESTS IN LOW-VISCOSTTY HYDROCARBON

[Bearing I.D., I $\frac{1}{2}$ in. (nominal); bearing length, $1 \frac{1}{2} \mathrm{in.}$ (nominal); journal materials, SAE 4340 and chromium plating on SAE 4340 ; surface finish, 5 to $10 \mathrm{\mu in.} \mathrm{(rms);} \mathrm{groove} \mathrm{type,} \mathrm{see} \mathrm{fig.} \mathrm{2(a).]}$

(b) Plastics

\begin{tabular}{|c|c|c|c|c|c|c|c|c|}
\hline \multirow[t]{2}{*}{ Bear ing material } & \multirow{2}{*}{$\begin{array}{c}\text { Room- } \\
\text { temperature } \\
\text { diametral } \\
\text { clearance, } \\
\text { in. }\end{array}$} & \multicolumn{2}{|c|}{$\begin{array}{c}\text { Maximum journal } \\
\text { speed }\end{array}$} & \multirow{2}{*}{$\begin{array}{l}\text { Maximum unit- } \\
\text { bearing load, } \\
\text { psi }\end{array}$} & \multirow{2}{*}{$\begin{array}{l}\text { Time at maximum } \\
\text { speed and load, } \\
\text { min }\end{array}$} & \multirow{2}{*}{$\left|\begin{array}{c}\text { Total } \\
\text { test } \\
\text { time, } \\
\text { min }\end{array}\right|$} & \multirow[t]{2}{*}{$\begin{array}{l}\text { Reason for } \\
\text { stopping test }\end{array}$} & \multirow[t]{2}{*}{$\begin{array}{l}\text { Bearing surface } \\
\text { condition }\end{array}$} \\
\hline & & rpm & $\mathrm{ft} / \mathrm{sec}$ & & & & & \\
\hline \multirow[t]{2}{*}{$\begin{array}{l}\text { PTFE resin } \\
\text { (extruded tubing) }\end{array}$} & 0.0015 & 2,500 & 16.5 & 17 & 2 & 2 & Seized & $\begin{array}{l}\text { Darkened area in load zone } \\
\text { Indicating high heating }\end{array}$ \\
\hline & 0.0083 & 10,000 & 66 & 17 & 10 & 85 & Rough operation & $\begin{array}{l}\text { Darkened area in load zone } \\
\text { indicating high heating }\end{array}$ \\
\hline \multirow{5}{*}{$\begin{array}{l}\text { PTFE resin plus } \\
\text { 20 percent copper } \\
\text { (extruded tubing) }\end{array}$} & 0.0064 & 14,500 & 96 & 17 & 30 & 90 & $\begin{array}{l}\text { Test objective } \\
\text { attained }\end{array}$ & Did not examine \\
\hline & & 14,500 & 96 & 44 & 30 & 120 & $\begin{array}{l}\text { Test objective } \\
\text { attained }\end{array}$ & Did not examine \\
\hline & & 5,000 & 33 & 87 & 2 & 120 & $\begin{array}{l}\text { High torque; motor } \\
\text { overload }\end{array}$ & $\begin{array}{c}\text { Pollshed area in load zone; } \\
\text { copper transfer to journal } \\
\text { surface }\end{array}$ \\
\hline & $b_{0} 0.0050$ & 15,000 & 99 & 44 & 15 & 120 & High torque & $\begin{array}{l}\text { Wear pattern indicated } \\
\text { probable misalinement }\end{array}$ \\
\hline & & 10,000 & 66 & 87 & 30 & 90 & $\begin{array}{l}\text { Seized in attempt } \\
\text { to Increase speed }\end{array}$ & $\begin{array}{l}\text { Distressed area on one end } \\
\text { only; large amount of copper } \\
\text { wear debris }\end{array}$ \\
\hline \multirow{5}{*}{$\begin{array}{l}\text { Fused PTFE resin on } \\
\text { wrought nickel- } \\
\text { copper alloy } \\
\text { (ASTM BI64) }\end{array}$} & 0.0025 & 15,000 & 107 & 40 & 30 & 150 & $\begin{array}{l}\text { Test objective } \\
\text { attained }\end{array}$ & Did not examine \\
\hline & & & & 81 & 30 & 105 & $\begin{array}{l}\text { Test objective } \\
\text { attained }\end{array}$ & Did not examine \\
\hline & & & & 122 & 30 & 90 & $\begin{array}{l}\text { Test objective } \\
\text { attained }\end{array}$ & Did not examine \\
\hline & & & & 163 & 30 & 90 & $\begin{array}{l}\text { Test objective } \\
\text { attalned }\end{array}$ & Did not examine \\
\hline & & & & 204 & 30 & 90 & $\begin{array}{l}\text { Test objective } \\
\text { attalned }\end{array}$ & $\begin{array}{c}\text { Bearing surface excellent; } \\
\text { light polishing in load zone } \\
\text { (fig. 6) }\end{array}$ \\
\hline
\end{tabular}




\begin{tabular}{|c|c|c|c|c|c|c|c|c|}
\hline \multirow{4}{*}{$\begin{array}{l}\text { Fused PTFCE }{ }^{\text {c }} \text { resin } \\
\text { on wrought nickel- } \\
\text { copper alloy } \\
\text { (ASTM Bl64) }\end{array}$} & \multirow[t]{4}{*}{0.0037} & \multirow[t]{3}{*}{15,000} & \multirow[t]{3}{*}{107} & 40 & 30 & 120 & $\begin{array}{l}\text { Test objective } \\
\text { attained }\end{array}$ & Did not examine \\
\hline & & & & $\overline{81}$ & 30 & 90 & $\begin{array}{l}\text { Test objective } \\
\text { attained }\end{array}$ & Did not examine \\
\hline & & & & 122 & 30 & 90 & $\begin{array}{l}\text { Test objective } \\
\text { attained }\end{array}$ & Did not examine \\
\hline & & $\widehat{14,000}$ & 100 & 163 & --- & 60 & $\begin{array}{l}\text { Rapid torque } \\
\text { Increase } \\
14,000 \mathrm{rpm}\end{array}$ & $\begin{array}{c}\text { Liner wiped In narrow band } \\
\text { at center extending } 360^{\circ} \text {; } \\
\text { evidence of high temperature } \\
\text { material breakdown }\end{array}$ \\
\hline \multirow[t]{4}{*}{$\begin{array}{l}\text { PTFE plus lead in } \\
\text { sintered bronze }\end{array}$} & \multirow[t]{4}{*}{0.0038} & \multirow[t]{4}{*}{15,000} & \multirow[t]{4}{*}{99} & 53 & 30 & 90 & $\begin{array}{l}\text { Test objective } \\
\text { attained }\end{array}$ & Did not examine \\
\hline & & & & 107 & 30 & 90 & $\begin{array}{l}\text { Test objective } \\
\text { attained }\end{array}$ & Did not examine \\
\hline & & & & 160 & 30 & 90 & $\begin{array}{l}\text { Test objective } \\
\text { attalned }\end{array}$ & Did not examine \\
\hline & & & & 213 & 30 & 90 & $\begin{array}{l}\text { Test objective } \\
\text { attained }\end{array}$ & $\begin{array}{l}\text { IIghtly polished area in lead } \\
\text { zone, otherwise surface } \\
\text { condition excellent ( } 1 \text { Ig. } 7 \text { ) }\end{array}$ \\
\hline
\end{tabular}

$a_{\text {Polytetrafluoroethylene. }}$

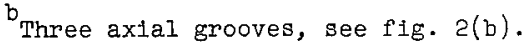

${ }^{c}$ Polytrifluorochloroethylene. 
TABLE I. - Concluded. RESULTS OF SCREENING TESTS IN LOW-VISCOSITT HYDROCARBON.

[Bearing I.D., l $\frac{1}{2}$ in. (nominal); bearing length, $1 \frac{1}{2}$ in. (nominal); journal materials, SAE 4340 and chromium plating on SAE 4340 ; surface finish, 5 to $10 \mu \mathrm{in}$. (rms); groove type, see fig. 2(a).]

(c) Ceramics and cermets

\begin{tabular}{|c|c|c|c|c|c|c|c|c|}
\hline \multirow[t]{2}{*}{ Bearing material } & \multirow{2}{*}{$\begin{array}{l}\text { Room- } \\
\text { temperature } \\
\text { diametral } \\
\text { clearance, } \\
\text { In. }\end{array}$} & \multicolumn{2}{|c|}{$\begin{array}{l}\text { Maximum journal } \\
\text { speed }\end{array}$} & \multirow{2}{*}{$\begin{array}{l}\text { Maximum unit- } \\
\text { bearing load, } \\
\text { psi }\end{array}$} & \multirow{2}{*}{$\begin{array}{l}\text { Time at maximum } \\
\text { speed and load, } \\
\text { min }\end{array}$} & \multirow{2}{*}{$\begin{array}{l}\text { Total } \\
\text { test } \\
\text { time } \\
\text { min }\end{array}$} & \multirow[t]{2}{*}{$\begin{array}{l}\text { Reason for } \\
\text { stopping test }\end{array}$} & \multirow[t]{2}{*}{$\begin{array}{l}\text { Bearing surface } \\
\text { condition }\end{array}$} \\
\hline & & rpm & $\mathrm{ft} / \mathrm{sec}$ & & & & & \\
\hline $\begin{array}{c}\text { Aluminum oxide } \\
\text { on flame-sprayed } \\
\text { wrought nickel- } \\
\text { copper alloy } \\
\text { (ASTM Bl64) }\end{array}$ & 0.0022 & 5,000 & 33 & 17 & -- & 1 & Sejzed & $\begin{array}{l}\text { Bearing surface darkened } \\
\text { in load zone. Metal } \\
\text { transferred from journal } \\
\text { to bearling surface }\end{array}$ \\
\hline \multirow[t]{2}{*}{$\begin{array}{c}\text { Crystallized glass } \\
\text { ceramic }\end{array}$} & 0.0011 & 10,000 & 66 & 44 & --- & 30 & Seized & $\begin{array}{c}\text { Bearing and journal welded } \\
\text { together }\end{array}$ \\
\hline & 0.0032 & 8,000 & 53 & 44 & $-\ldots$ & 30 & Selzed & $\begin{array}{l}\text { Darkened circumferential bands } \\
1 / 4 \mathrm{in.} \text { in from ends }\end{array}$ \\
\hline \multirow[t]{2}{*}{$\begin{array}{l}\text { Platinum-bonded } \\
\text { titanium carbide }\end{array}$} & 0.0022 & 9,000 & 59 & 44 & $\overline{---}$ & 90 & Seized & $\begin{array}{l}\text { Distressed area localized at } \\
\text { bearing ends extending around } \\
\text { circumference }\end{array}$ \\
\hline & 0.0018 & 9,000 & 59 & 44 & --- & $i^{45}$ & Seized & $\begin{array}{l}\text { Distressed area localized at } \\
\text { bearing ends extending around } \\
\text { circumference }\end{array}$ \\
\hline
\end{tabular}


TABLE II. - RESULTS OF SCREENING TESTS IN LIQUID NITROGEN

[Bearing I.D., I In. (nominal); bearing length, I In. (nominal); journal surface finish 5 to lo $\mu$ in. (rms); nitrogen absolute viscosity $\mu$, $0.023 \times 10^{-6}$ reyns at $-320^{\circ} \mathrm{F}$ (b.p.).]

\begin{tabular}{|c|c|c|c|c|c|c|c|c|c|c|c|}
\hline \multirow[t]{2}{*}{ Bearling materlai } & \multirow[t]{2}{*}{ Journal materlal } & \multirow[t]{2}{*}{$\begin{array}{c}\text { Groove type, } \\
\text { see - }\end{array}$} & \multicolumn{2}{|c|}{$\begin{array}{l}\text { Diametral clearance, } \\
\text { in. }\end{array}$} & \multicolumn{2}{|c|}{$\begin{array}{c}\text { Maximum journal } \\
\text { speed }\end{array}$} & \multirow{2}{*}{$\begin{array}{l}\text { Maxi- } \\
\text { mum } \\
\text { un1t } \\
\text { load, } \\
\text { psi }\end{array}$} & \multirow{2}{*}{$\begin{array}{l}\text { Time at } \\
\text { maximum } \\
\text { speed } \\
\text { and } \\
\text { load, } \\
\text { min }\end{array}$} & \multirow{2}{*}{$\begin{array}{c}\text { Total } \\
\text { test } \\
\text { time, } \\
\text { m.n }\end{array}$} & \multirow[t]{2}{*}{$\begin{array}{l}\text { Reason for } \\
\text { stopping test }\end{array}$} & \multirow[t]{2}{*}{$\begin{array}{l}\text { Bearing surface } \\
\text { condltion }\end{array}$} \\
\hline & & & $\begin{array}{l}\text { Room } \\
\text { tem- } \\
\text { per- } \\
\text { ature }\end{array}$ & $\begin{array}{l}\text { Liquid- } \\
\text { nitrogen } \\
\text { temperature } \\
\text { (a) }\end{array}$ & rpm & $\overline{f^{\prime} t / \sec }$ & & & & & \\
\hline \multirow{4}{*}{$\begin{array}{l}\text { SAE-64-bearing } \\
\text { bronze } \\
\left(80 \% \mathrm{Cu}^{+}+10 \% \mathrm{~Pb}\right. \\
+10 \% \mathrm{Sn})\end{array}$} & \multirow[t]{4}{*}{ SAE 4340} & F1g. 2(e) & 0.0040 & 0.0025 & 20,000 & 87.5 & 25 & 5 & 95 & $\begin{array}{l}\text { Ran out of liquid } \\
\text { nitrogen }\end{array}$ & $\begin{array}{l}\text { Wear pattern in upper half of } \\
\text { bearing load zone, journal } \\
\text { surface excellent }\end{array}$ \\
\hline & & $\mathrm{F} \pm \mathrm{g} \cdot \mathrm{2(e)}$ & 0.0035 & 0.0022 & 7,500 & 32.7 & 25 & 5 & 60 & $\begin{array}{l}\text { Selzed at } \\
10,000 \mathrm{rpm} \\
\text { and } 25 \mathrm{psi}\end{array}$ & $\begin{array}{c}\text { Distressed area in load zone; } \\
\text { bearing had rotated in 1ts } \\
\text { housing }\end{array}$ \\
\hline & & $\mathrm{F} 1 \mathrm{~g} \cdot 2(\mathrm{~g})$ & 0.0041 & 0.0025 & 2,000 & 8.8 & 36 & 5 & 25 & $\begin{array}{l}\text { Excessive motor } \\
\text { amperes }\end{array}$ & $\begin{array}{l}\text { Surface galled and scored at } \\
\text { bearing extremities }\end{array}$ \\
\hline & & Fig. 2(e) & 0.0033 & 0.0020 & 1,100 & 4.8 & 25 & 2 & 20 & $\begin{array}{c}\text { Excessive motor } \\
\text { amperes }\end{array}$ & $\begin{array}{c}\text { Uneven wear indicating } \\
\text { misalinement }\end{array}$ \\
\hline \multirow[t]{4}{*}{$\begin{array}{l}\text { H1gh-lead-bearing } \\
\text { bronze } \\
(70 \% \mathrm{Cu}+26 \% \mathrm{~Pb} \\
+4 \% \mathrm{Sn})\end{array}$} & \multirow[t]{4}{*}{$\begin{array}{l}\text { Precipitation } \\
\text { hardened } \\
\text { stainless steel }\end{array}$} & $\begin{array}{l}\text { F1g. } 2(\mathrm{e}) \\
\text { but only } \\
\text { one axial }\end{array}$ & 0.0035 & $-\cdots-$ & 2,700 & 11.8 & $-\ldots$ & 15 & 25 & $\begin{array}{l}\text { High motor } \\
\text { amperes }\end{array}$ & Wear at bearing upper end only \\
\hline & & Fig, 2(e) & 0.0037 & ----- & 5,000 & 21.8 & $\overline{---}$ & 10 & 25 & $\begin{array}{l}\text { Sefized after I min } \\
\text { at } 5000 \mathrm{rpm} \text { and } \\
30 \mathrm{ps} 1 \text { load }\end{array}$ & $\begin{array}{l}\text { Lead smeared on surface in } \\
\text { loaded half of bearing. } \\
\text { Journal scored and polished }\end{array}$ \\
\hline & & Fig. 2(e) & 0.0038 & $-\cdots--$ & 5,000 & 21.8 & -- & 20 & 43 & $\begin{array}{l}\text { High motor } \\
\text { amperes }\end{array}$ & $\begin{array}{l}\text { Bearing surface galled, } \\
\text { moved in housing }\end{array}$ \\
\hline & & Fig. 2(f) & 0.0030 & $\overline{n-n-1}$ & 2,500 & 10.9 & $\overline{---}$ & 3 & 30 & $\begin{array}{l}\text { High motor } \\
\text { amperes }\end{array}$ & $\begin{array}{l}\text { Distressed area on upper half } \\
\text { of bearing }\end{array}$ \\
\hline \multirow{3}{*}{$\begin{array}{l}\text { Fused PTFE resin on } \\
\text { wrought nickel- } \\
\text { copper alloy }\end{array}$} & \multirow{3}{*}{$\begin{array}{l}\text { Wrought nickel- } \\
\text { copper alloy } \\
\text { (ASTM Bl64) }\end{array}$} & F1g. 2(e) & 0.0070 & 0.0045 & 25,000 & 109 & 36 & 15 & 105 & $\begin{array}{l}\text { Test objective } \\
\text { obtained }\end{array}$ & $\begin{array}{l}\text { Bearing surface good, slight } \\
\text { polish1ng in load zone }\end{array}$ \\
\hline & & Fig. 2(e) & 0.0070 & 0.0045 & 7,500 & 32.7 & 18 & 5 & $\$ 0$ & Severe vibrations & $\begin{array}{l}\text { PTFE liner worn through to } \\
\text { wrought nlckel-copper alloy } \\
\text { sleeve }\end{array}$ \\
\hline & & Fig. $2(e)$ & 0.013 & 0.0105 & 15,000 & 65.5 & 215 & 5 & 85 & $\begin{array}{c}\text { Test objective } \\
\text { obtained }\end{array}$ & $\begin{array}{l}\text { Liner worn excessively in } \\
\text { bonded area }(\mathrm{f} \perp \mathrm{g} .7(\mathrm{a}))\end{array}$ \\
\hline \multirow[t]{4}{*}{$\begin{array}{l}\text { PTFE plus lead in } \\
\text { sintered bronze }\end{array}$} & \multirow[t]{4}{*}{$\begin{array}{l}\text { Freclpitation } \\
\text { hardened } \\
\text { stainless steel }\end{array}$} & None & 0.0011 & ----- & 8,000 & 34.9 & $\overline{36}$ & 7 & 90 & $\begin{array}{l}\text { High motor } \\
\text { amperes }\end{array}$ & $\begin{array}{l}\text { Lead-PTFE overlay worn away in } \\
\text { loaded area of bearting surface }\end{array}$ \\
\hline & & None & 0.0016 & ---- & 1,000 & 4.4 & 36 & 15 & 60 & $\begin{array}{l}\text { High motor } \\
\text { amperes }\end{array}$ & Slight wear in loaded half \\
\hline & & Fig. 2(d) & 0.0052 & ----- & 20,000 & 87.5 & 45 & 2 & $\overline{95}$ & $\begin{array}{l}\text { High motor } \\
\text { amperes }\end{array}$ & $\begin{array}{l}\text { Bearing was found to have lost } \\
\text { 1ts in1tial pressure. Fitting } \\
\text { was loose } 1 \text { h housing } \\
(\text { Flg } 7(\mathrm{~b}))\end{array}$ \\
\hline & & None & 0.0068 & ----- & 7,500 & 32.7 & 17 & 3 & 65 & $\begin{array}{l}\text { Excessive noise; } \\
\text { high amperes }\end{array}$ & $\begin{array}{l}\text { Wear in load zone through to } \\
\text { sintered-bronze underlay }\end{array}$ \\
\hline
\end{tabular}

${ }^{a_{\text {Calculated. }}}$. 
TABLE III. - RESULTS OF TESTS IN LIQUTD OXYGEN

[Bearing I.D., I In. (nominal); bearing length, I In. (nom1nal) except where noted; journal surface finish, 5 to lo win. ( $2 m s$ ); absolute viscosity u, $0.0274 \times 10^{-6}$ reyns at $-297^{\circ} \mathrm{F}(\mathrm{b} . \mathrm{p}$.$) .$

(a) Fuliy immersed at atmospheric pressure

\begin{tabular}{|c|c|c|c|c|c|c|c|c|c|c|c|}
\hline \multirow[t]{2}{*}{ Bearing material } & \multirow[t]{2}{*}{ Journal material } & \multirow[t]{2}{*}{$\begin{array}{c}\text { Groove type, } \\
\text { see - }\end{array}$} & \multicolumn{2}{|c|}{$\begin{array}{c}\text { Dlametral clearance, } \\
\text { in. }\end{array}$} & \multicolumn{2}{|c|}{$\begin{array}{c}\text { Maximum journal } \\
\text { speed }\end{array}$} & \multirow{2}{*}{$\begin{array}{c}\text { Maxi- } \\
\text { mumm } \\
\text { undt } \\
\text { load, } \\
\text { ps1 }\end{array}$} & \multirow{2}{*}{\begin{tabular}{|c|} 
Time at \\
maximum \\
speed \\
and \\
load, \\
min
\end{tabular}} & \multirow{2}{*}{$\left|\begin{array}{c}\text { Total } \\
\text { test } \\
\text { time, } \\
\text { min }\end{array}\right|$} & \multirow[t]{2}{*}{$\begin{array}{l}\text { Reason for } \\
\text { stopping test }\end{array}$} & \multirow[t]{2}{*}{$\begin{array}{l}\text { Bearing surface } \\
\text { condition }\end{array}$} \\
\hline & & & \begin{tabular}{|l|} 
Room \\
tem- \\
per- \\
ature
\end{tabular} \mid & $\begin{array}{c}\text { Liquid- } \\
\text { oxygen } \\
\text { temperature } \\
\text { (a) }\end{array}$ & $\mathrm{rpm}$ & $\mathrm{ft} / \mathrm{sec}$ & & & & & \\
\hline $\begin{array}{l}\text { SAE-64-bearing } \\
\text { bronze }\end{array}$ & $\begin{array}{l}\text { Precipitation } \\
\text { hardened } \\
\text { stainless steel }\end{array}$ & $F 1 g \cdot 2(g)$ & 0.0040 & 0.0035 & 1,000 & 4.4 & -- & -- & 3 & $\begin{array}{c}\text { Selzed when } \\
\text { increasing speed }\end{array}$ & $\begin{array}{l}\text { Distressed area upper one- } \\
\text { third surface, loaded half }\end{array}$ \\
\hline $\begin{array}{c}\text { H1gh-lead-bearting } \\
\text { bronze }\end{array}$ & $\begin{array}{l}\text { Precipltation hard- } \\
\text { ened sta1nless steel }\end{array}$ & $F \perp g \cdot 2(g)$ & 0.0052 & 0.0044 & 1,000 & 4.4 & $-\cdots$ & 4 & 10 & $\begin{array}{c}\text { Selzed when } \\
\text { Increasing speed }\end{array}$ & $\begin{array}{l}\text { Extensive scoring on bearing } \\
\text { surface near upper end }\end{array}$ \\
\hline \multirow[t]{2}{*}{$\begin{array}{l}\text { Fused PIFE on } \\
\text { wrought nfcke1- } \\
\text { copper alloy }\end{array}$} & \multirow[t]{2}{*}{$\begin{array}{l}\text { Precipitation } \\
\text { hardened } \\
\text { stainless steel }\end{array}$} & Fig. 2(d) & 0.0037 & 0.0047 & 17,500 & 76.5 & 36 & 5 & 63 & $\begin{array}{c}\text { High motor amperes, } \\
\text { notse }\end{array}$ & $\begin{array}{l}\text { Bearing-liner worn through to } \\
\text { wrought nickel-copper alloy } \\
\text { sleeve }\end{array}$ \\
\hline & & None & 0.0092 & 0.0115 & 10,000 & 44 & 36 & 10 & 37 & $\begin{array}{l}\text { Lower test shaft } \\
\text { seal fallure }\end{array}$ & $\begin{array}{c}\text { L1ght polishing in load zone; } \\
\text { journal surface highly } \\
\text { polished }\end{array}$ \\
\hline \multirow[t]{2}{*}{$\begin{array}{l}\text { PTFE plus lead 1n } \\
\text { sintered bronze }\end{array}$} & \multirow{2}{*}{$\begin{array}{l}\text { Precip1tation } \\
\text { hardened } \\
\text { stalnless steel }\end{array}$} & $F \perp g \cdot 2(d)$ & 0.0029 & 0.0005 & 10,000 & 44 & 36 & 5 & 55 & $\begin{array}{l}\text { Se1zed at } \\
12,800 \mathrm{rpm}\end{array}$ & $\begin{array}{l}\text { Light wear in load zone; clear- } \\
\text { ance too small }(\mathrm{f} 1 \mathrm{~g} . \mathrm{g}(\mathrm{b}))\end{array}$ \\
\hline & & None & 0.0088 & $0 . \overline{001 \overline{3}}$ & 6,000 & 26.2 & 37 & 7 & 93 & $\begin{array}{l}\text { High motor amperes } \\
\text { when applytng load }\end{array}$ & $\begin{array}{l}\text { Light wear in load zone; } \\
\text { surface good }\end{array}$ \\
\hline \multirow[t]{2}{*}{$\begin{array}{c}\text { PTFE on steel } \\
(15 \% \text { glass f1lled) }\end{array}$} & \multirow[t]{2}{*}{$\begin{array}{l}\text { Preclpitation } \\
\text { hardened } \\
\text { stainless steel }\end{array}$} & None & 0.0080 & 0.0049 & 15,000 & 65.5 & 160 & 7 & 57 & $\begin{array}{c}\text { Se1zed at } \\
25,000 \mathrm{rpm} \text { and } \\
44 \mathrm{psi} \text { load }\end{array}$ & $\begin{array}{c}\text { PTFE liner worn excessively; } \\
\text { journal shows evidence of } \\
\text { heating }\end{array}$ \\
\hline & & None & 0.012 & 0.006 & 10,000 & 44 & 14 & 3 & 34 & High motor amperes & $\begin{array}{l}\text { High wear in load zone } \\
0.004 \text { out of round (f1g. } 8(\mathrm{a}))\end{array}$ \\
\hline \multirow[t]{2}{*}{$\begin{array}{l}\text { Mechanical carbon } \\
\text { phenolic-resin } \\
\text { Impregnate }\end{array}$} & \multirow[t]{2}{*}{$\begin{array}{l}\text { Chromium plating } \\
\text { on steel }\end{array}$} & $\begin{array}{l}\text { F1g. } 2(e) \\
\text { only one } \\
\text { groove }\end{array}$ & 0.0022 & 0.0012 & 2,600 & 11.3 & --- & 13 & 25 & High motor amperes & $\begin{array}{l}\text { Surface rough and pitted in } \\
\text { loaded area; journal shows } \\
\text { carbon material transfer }\end{array}$ \\
\hline & & Fig. 2(e) & 0.0050 & 0.0018 & 1,000 & 4.4 & --- & 3 & 3 & $\begin{array}{c}\text { Seized at } \\
2500 \mathrm{rpm} ; \text { no load }\end{array}$ & $\begin{array}{l}\text { Surface rough and pitted in } \\
\text { loaded area; journal shows } \\
\text { carbon materlal transfer }\end{array}$ \\
\hline
\end{tabular}

${ }^{a}$ Calculated.

bolytetrafluroethylene.

${ }^{c}$ Radial hole 1n journal wail, 1/8-1n. diameter.

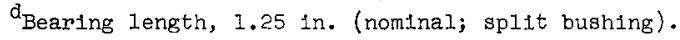


TAELE III. - Concluded. RESULTS OF TESTS IN LIQUID OXYGEN [Bearing I.D., I In. (nominal); bearing length, I 1n. (nominal) except where noted; journal surface finish, 5 to $10 \mu$ in. (rms); absolute viscosity $\mu$,

(b) Externally pressurized at 5 pounds per square inch gage (b.p., $-302^{\circ} \mathrm{F}$ )

1

\begin{tabular}{|c|c|c|c|c|c|c|c|c|c|c|c|}
\hline \multirow[t]{2}{*}{ Bearling material } & \multirow[t]{2}{*}{ Journal material } & \multirow[t]{2}{*}{$\begin{array}{c}\text { Groove type, } \\
\text { see - }\end{array}$} & \multicolumn{2}{|c|}{$\begin{array}{c}\text { Dlametral clearance, } \\
\text { In. }\end{array}$} & \multicolumn{2}{|c|}{$\begin{array}{c}\text { Maxlmum journal } \\
\text { speed }\end{array}$} & \multirow{2}{*}{$\begin{array}{c}\text { Maxi- } \\
\text { mum } \\
\text { un1t } \\
\text { load, } \\
\text { psi }\end{array}$} & \multirow{2}{*}{$\begin{array}{l}\text { Time at } \\
\text { maximum } \\
\text { speed } \\
\text { and } \\
\text { load, } \\
\text { min }\end{array}$} & \multirow{2}{*}{$\begin{array}{l}\text { Total } \\
\text { test } \\
\text { time } \\
\text { min }\end{array}$} & \multirow[t]{2}{*}{$\begin{array}{l}\text { Reason for } \\
\text { stopping test }\end{array}$} & \multirow[t]{2}{*}{$\begin{array}{l}\text { Bearing surface } \\
\text { condition }\end{array}$} \\
\hline & & & $\begin{array}{l}\text { Room } \\
\text { tem-- } \\
\text { per- } \\
\text { ature }\end{array}$ & $\begin{array}{l}\text { Liquid- } \\
\text { oxygen } \\
\text { temperature } \\
\text { (a) }\end{array}$ & $\mathrm{rpm}$ & $\mathrm{ft} / \mathrm{sec}$ & & & & & \\
\hline \multirow{2}{*}{$\begin{array}{l}\text { Fused PTFE on } \\
\text { wrought nickel- } \\
\text { copper alloy }\end{array}$} & \multirow[t]{2}{*}{$\begin{array}{l}440-C \text { stalnless } \\
\text { steel }\end{array}$} & None & 0.0096 & $\overline{----1}$ & 8,000 & 34.9 & 36 & 10 & 55 & $\begin{array}{l}\text { High motor amperes } \\
\text { and rig vibration }\end{array}$ & $\begin{array}{c}\text { I1ner completely worn away in } \\
\text { loaded area }\end{array}$ \\
\hline & & None & 0.0087 & ---- & 10,000 & 44 & 41 & 8 & 50 & $\begin{array}{l}\text { H1gh motor amperes } \\
\text { and rig vibration }\end{array}$ & $\begin{array}{l}\text { Liner completely worn away in } \\
\text { loaded area (fig. } g(a))\end{array}$ \\
\hline \multirow[t]{3}{*}{$\begin{array}{l}\text { Mechanical carbon } \\
\text { phenolic-resin } \\
\text { lmpregnate }\end{array}$} & \multirow[t]{3}{*}{$\begin{array}{l}\text { Chromium plating } \\
\text { on steel }\end{array}$} & FIg. I(a) & 0.0038 & ----- & 10,000 & 44 & 20 & 2 & 37 & Seized & $\begin{array}{c}\text { Roughened band extending } 360^{\circ} \\
\text { clrcumferentially at bearing } \\
\text { center }\end{array}$ \\
\hline & & Fig. $I(a)$ & 0.0030 & $-\cdots-$ & 1,100 & 4.8 & --- & --- & 20 & High motor amperes & $\begin{array}{l}\text { Polished area in load zone; } \\
\text { journal evidences resin stain }\end{array}$ \\
\hline & & $F+g \cdot 2(d)$ & 0.0030 & ---- & 6,000 & 26.2 & 26 & 2 & 54 & Seized & $\begin{array}{l}\text { Pollshed area in load zone, } \\
\text { roughened band extending } 360^{\circ} \\
\text { clrcumferentially. Journal } \\
\text { evidences high heating }\end{array}$ \\
\hline \multirow[t]{2}{*}{$\begin{array}{l}\text { Mechanical carbon } \\
\text { plus halide-salt } \\
\text { Impregnate }\end{array}$} & \multirow[t]{2}{*}{$\begin{array}{l}\text { Chromium plating } \\
\text { on steel }\end{array}$} & F1g. 2(a) & 0.0034 & ----- & 460 & 2 & --- & 10 & 10 & High motor amperes & $\begin{array}{c}\text { Brown film at lower end of } \\
\text { bearing. } \\
\text { Journal had } \\
\text { excessive taper }\end{array}$ \\
\hline & & $F \geq g \cdot 2(a)$ & 0.0025 & $\cdots--$ & 6,000 & 26.2 & 26 & 2 & 54 & $\begin{array}{l}\text { Fluctuating motor } \\
\text { amperes; rig nolsy }\end{array}$ & $\begin{array}{l}\text { Highly polished area in load } \\
\text { zone; clrcumferential } \\
\text { scoring at bearlng ends }\end{array}$ \\
\hline $\begin{array}{c}\text { Mechanical carbon } \\
\text { plus hallde-salt } \\
\text { 1mpregnate } \\
\text { and PTFCE f1lm }\end{array}$ & $\begin{array}{l}\text { Chromium plating } \\
\text { on steel }\end{array}$ & $\mathrm{F} 1 \mathrm{~g} \cdot 2(\mathrm{a})$ & 0.0031 & -n-- & 8,000 & 34.9 & 36 & 15 & 65 & $\begin{array}{c}\text { Se1zed at } \\
10,000 \mathrm{rpm} \text { and } \\
36 \mathrm{psi} \text { load }\end{array}$ & $\begin{array}{l}\text { Wear bands extending } 360^{\circ} \text { and } \\
1 / 4 \text { in. from ends; debris in } \\
\text { groove (fig. } 9(\mathrm{~b}))\end{array}$ \\
\hline \multirow[t]{3}{*}{$\begin{array}{l}\text { Mechantcal carbon } \\
\text { plus PTFE } \\
\text { Impregnate }\end{array}$} & \multirow[t]{3}{*}{$\begin{array}{l}\text { Chromium plating } \\
\text { on steel }\end{array}$} & \multirow[t]{3}{*}{$F \perp g, 2(a)$} & 0.0032 & $\cdots$ & 2,000 & 8.7 & 17 & 12 & 55 & $\begin{array}{l}\text { Fluctuating motor } \\
\text { amperes; rig nolsy }\end{array}$ & $\begin{array}{l}\text { Highly polished area, lower } \\
\text { one-half of bearing. Journal } \\
\text { has carbon plckup }\end{array}$ \\
\hline & & & 0.0032 & $\ldots$ & 8,000 & 34.9 & 20 & 8 & 48 & $\begin{array}{l}\text { High armature } \\
\text { amperes }\end{array}$ & $\begin{array}{l}\text { Highly polished area in center } \\
\text { of load zone; flim transfer in } \\
\text { journal center }\end{array}$ \\
\hline & & & 0.0032 & ---- & 2,000 & 8.7 & 27 & 5 & 47 & $\begin{array}{l}\text { High armature } \\
\text { amperes }\end{array}$ & $\begin{array}{l}\text { Highly polished area in center } \\
\text { of load zone; film transfer in } \\
\text { journal center (flg. } 9(\mathrm{c}))\end{array}$ \\
\hline
\end{tabular}

${ }^{a_{D i d}}$ not calculate because bearings were not fully immersed in Ilquid oxygen. 
"The aeronautical and space activities of the United States shall be conducted so as to contribute . . . to the expansion of buman knowledge of phenomena in the atmosphere and space. The Administration shall provide for the widest practicable and appropriate dissemination of information concerning its activities and the results thereof."

-National Aeronautics and Space Act of 1958

\section{NASA SCIENTIFIC AND TECHNICAL PUBLICATIONS}

TECHNICAL REPORTS: Scientific and technical information considered important, complete, and a lasting contribution to existing knowledge.

TECHNICAL NOTES: Information less broad in scope but nevertheless of importance as a contribution to existing knowledge.

TECHNICAL MEMORANDUMS: Information receiving limited distribution because of preliminary data, security classification, or other reasons.

CONTRACTOR REPORTS: Technical information generated in connection with a NASA contract or grant and released under NASA auspices.

TECHNICAL TRANSLATIONS: Information published in a foreign language considered to merit NASA distribution in English.

TECHNICAL REPRINTS: Information derived from NASA activities and initially published in the form of journal articles.

SPECIAL PUBLICATIONS: Information derived from or of value to NASA activities but not necessarily reporting the results of individual NASA-programmed scientific efforts. Publications include conference proceedings, monographs, data compilations, handbooks, sourcebooks, and special bibliographies.

Defails on the availability of these publications may be obtained from:

SCIENTIFIC AND TECHNICAL INFORMATION DIVISION

NATIONAL AERONAUTICS AND SPACE ADMINISTRATION

Washington, D.C. 20546 